Historic, archived document

Do not assume content reflects current scientific knowledge, policies, or practices. 



\section{U.S. DEPARTMENT OF AGRICULTURE.}

BUREAU OF ENTOMOLOGY.

Bulletin No. 5.

\section{DESCRIPTIONS OF NORTH AMERICAN}

\section{CHALCIDID $\mathbb{E}$}

FROM THE COLLECTIONS OF THE U. S. DEPARTIENT OF AGRICULTURE AND OF DR. C. V. RILEY,

WITH

\section{BIOLOGICAL NOTES.}

\section{[ FIRST PAPIER].}

TOGETHER WITH A LIST OF THE DESCRIBED NORTH AMERICAN SPECIES OF THE FAMILY.

BY

L. O. H OW A RD, M. Sc., ASSISTANT, BUREAU OF ENTOMOLOGY.

W $\triangle \mathrm{S}$ II INGTON :

GOVERNMENT PRINTING OFFIOE. 


\section{DepartMEet of Agriculture, Bureau of Extomology, \\ Washington, D. C., January 9, 1885.}

SIR: One of the obstacles which the economic entomologist encounters in this country is the impossibility of properly referring by name to the majority of the insect enemies and parasites of rery many of the most prominent injurious species. This difficulty has been greatly felt in the work of this Burean, and some endeavor has been made to have certain families, like the Tachinidæ and Syrphidæ in Diptera, Torked up. In the smaller Hymenoptera a very large amount of undescribed material has been reared, and as Mr. Howard has made a specialty of their stud 5 , I hare desired that he derote whaterer time he can well spare from his other duties, to working this material up. The paper herewith presented is the first of a series of descriptire papers which are intended to overcome the difficulty mentioned, and which, being technical and intended for circulation among entomologists, need only be printed in limited edition.

Respectfully,

C. V. RILET, Entomologist.

Dr. George B. LoRING,

Commissioner of Agriculture. 



\title{
FAMILY CHALCIDIDE.
}

\author{
Subfamily LEUCOSPIN Æ.
}

\section{Genus Leucospis Fabr.}

In this genus the fore wings are folded as with the true wasps, the bind femora are greatly thickened, the tibiæ are broadened at their extremities, and the oripositor of the female is curled up over the dorsum of the abdomen, usually reaching to the thorax.

\section{Leucospis affinis Say.}

This species is represented by two of specimens taken in Northern Virginia in September. It is a common species, found from ('auada to Texas, and is supposed to live in the nests of wild bees. [C. V. R. Coll.]

\section{Subfamily CHALCIDIN玉.}

The three genera which we shall consider in this subfamily may be separated as follows :

A. Abdomen petiolated

SPILOCHALCis.

B. Abdomen sessile.

a. Posterior tibia produced to a single spine at tip. Antenna inserted at the middle of the face................................... Ciralcis.

b. Posterior tibia two-spined. Antennæ inserted below the middle of the face.

\section{HaLtichella.}

Note.-In this first paper on the Chalcidide in the collection of the United states Department of Agriculture and that of Dr. C. V. Riley, which has been constantly used in the work of the Department, I have taken np the six subfamilies Lencospince, Chalcidince, Encyrtince, Aphelinina, Elachistinc, and Elasmina. In unmbers these subfamilies are not largely represented, but tho material is mainly muleseribed and is rendered vahable by the accompanying notes ou habits and dates of issuanee, which are connected with numbers in the collections. The hosts not specifieally referred to are undetermined by Dr. Riley, and are, so far as known, undescribed.

JANUARY $1,18 \div 5$.

L. O. HOWARI) 


\section{Genus Spilochalcis Thomson.}

Head triangular; antennæ separated at base by a triangular notched elevation; thorax usually marked with yellow; metathorax rugose ; fore wings with long marginal and postmarginal veins; abdomen, subglobose; petiole, moderately long, cylindrical; posterior margin of the femora densely serrate, except in missouriensis, which has four widely separated teeth; posterior tibiro produced into a spine, and middle tibice with a distinct spine.

2. (1) Spilochalcis marize (Riley).

This common parasite has been reared from the following insects: Antherce polyphemus.-24 ô, 23 \& specimens were bred from a cocoon of this species by $\mathrm{V}$. T. Chambers, at New Orleans, La., in 1869. The collection also contains specimens bred from the cocoons of this moth by Dr. Hoffmeister, at Fort Madison, Iowa. [C. V. R. Coll.]

Samia cecropia.-Specimens bred by Mrs. Treat, at Vineland, N. J. [C. V. R. Coli.]

Callosamia promethea.-Same as preceding. [C. V. R. Coll.]

Attacus cynthia.-From a lot of 202 cocoons received from $\mathrm{S}$. Lowell Elliot, New York City, were bred, in May, 1881, 113 ㅇ's, 36 o's. The former varied from $4^{\mathrm{mm}}$ to $8^{\mathrm{mm}}$ in length, and the latter from $3.5^{\mathrm{mm}}$ to $6^{\mathrm{mm}}$. [Dept. Agr. Coll.]

Specimens bred from this species were received from A. H. Mundt, Fairbury, Ill. [C. V. R. Coll.]

Thyridopteryx ephemercformis.-A specimen was bred from a bag of this insect, May 11, 1869, at Saint Louis. [C. V. R. Coll.]

\section{3. (2) Spilochalcis missouriensis n. sp.}

Female. - Length, $5^{\mathrm{mm}}$. Posterior femora with four widely separated teeth. Color, bright scarlet, marked with black as follows: Flagellnm of antennæ, with the exception of clul, at tip ; elspens and occiput; a large circular spot on the mesonotum; a transverse band on the metanotum; an irregular spot on each side near tip of abdomen; a large spot on each side of the thorax just below tegulæ; a dorsal spot near the tip of the posterior coxie; a minute circular spot on the dorsum of each hind femur, and two large round spots latero-ventrally, one in the middle and one at tip; spines of femur; a spot at the base of the hind tibiæ. The wings are slightly dusky, with a pronounced fuscous spot around clnb of stigmal vein; stigmal club securiform, entire; all wing veins brown.

Described from 1 captured o ( ô unknown), Saint Louis, Mo., July. [C. V. R. Coll.]

Seems to come nearer to Smicra lanieri (Guer.), Cuba, than to any other described species.

4. (3) Spilochalcis virens, 11. sp.

Male.-Length, $8^{\mathrm{mm}}$; expanse, $1 \mathrm{E}^{\mathrm{mm}}$; greatest width of fore wing, $3.2^{\mathrm{mm}}$. Resembles somewhat Sm. marice (hiley). Pedicel short and slender; hind femora, 12-15 toothed. Colors, black and jellow; facial grooves, vertex, and occiput black; remainder of head gellow; scape of antenux yellow, black above near tip; flagellum, black; first three joints brownish below; pronotum yellow, with a black spot anteriorly and one at each dorsal lateral anglo ; mesoscutum black, with four narrow longitudinal stripes; 
axilla yellow, black at tip; mesoscutellum yellow, with a broad central longitudinal black band; metanotum yellow, with a transverse black band and with two longitudinal lateral bands; pedicel black with a large yellow spot above; abdom en yellow, the joints above edged with black ; front and midrle legs entirely yellow, except that the middle coxa and trochanters are tinged with brown at base; hind coxa black, with a forked yellow stripe ontside and a broad yellow band inside; hind femora yellow, inner disk erlged with black, outer face with a short oblique tapering black stripe; hind tibie anil tarsi yellow, the former with a brown shade on the edge toward the femora; wings slightly clourly, veins yellow; stigmal club entire.

Described from 1 ô collected at Fort Madison, Iowa, by I)r. A. W. Holf̈meister. [U. T. R. Coll.]

5. (4) Spilochalcis odontotæ, u. sp.

Male. -Length of bod $5,2.4^{\mathrm{min}}$; expanse of wings, $5.4^{\mathrm{mm}}$. General color light lemonyellow; flagellum of antenue with a strong ferrugiuous tinge; occipnt, black; pronotum with a small black spot on either sirle; mesocutum with a merlian fatutly-defiued black spot; mesoscutellım with a similar well-defined spot; borders of all mesonotal sutnres black, the posterior and outer borders of the scapula more widely edged with black than the other parts; metanotum and metasternum with blackish patches; pedicel nearls white, semi-transparent; abdomen, honer-yellow, eisch segment edged with black, second segment bright lemon-rellow; legs nearly white; hind coxæ with a dusky spot at internal base; teeth of hind femora black, and both hind femora and tibie faintly mottled with ferruginous. Wings clear; reins nearly black ; stigmal club slightly notched.

Described from 1 os specimen, bred July 31, 18st, from the pupa of Odontota scutellaris, mining leares of Robinia pseulacacia at Washingtou, D. C. [C. V. R. Coll.]

6. (5) Spilochalcis delira, (Cress).

This species was described by Cressou from a male specimen collected in Texas by Belfrage. Tro females studied in this connection, one taken by Mr. Schwarz in Florida (Haw Creek), in July, 1883 [Dept. Agr. Coll.], and the other collected on cotton by Mr. Patton, at Selma, Ala., Uctober, 1881 [U. V. R. Coll.], seem without much doubt referable to this species, and I so place them pending an actual comparison of specimens.

7. (6) Spilochalcis albifrons (Walsh).

This is the species deseriber by Walsh (Trans. Ill. State Agr. Soc. iv., 1861) as a secoudary parasite ou his Pezomachus minimus, bred from the army worm (Leucuniu unipunctu, Haw.). It was originally described as a Chalcis, but evidently belongs in Spilochalcis. It is represented by one poor specimen. [C. V. R. Coll.]

\section{Gemus CHalcis Fabr.}

Head short, triangular ; antennie insorted a little below the midhle of the face, their bases but slightly separaterl, and the soipe entiroly enntainerl within the antenual groove; postmarginal vein of the fore wings shorter than the marginal ; abdomen almost sessile, oblong, subtriangular; anterior fomora subfusiform, posterior ovate, with a crenate lower margin; michllo tibia each with a spur at tip; posterior tibia prolouged at tip into a spur. 
8. (1) Chalcis ovata Say.

A number of specimens of this species occur in the collections. They vary greatly in size (between $6^{\mathrm{mm}}$ and $3^{\mathrm{mm}}$ in length), and were bred from the following insects:

Thyridopteryx ephemercformis.-Specimens were bred October 14, 1582, from bags of this species collected at Washington, D. C. [Dept. Agr. Coll.]

A patura clyton.-Specimens were bred, September 17, 1S78, from the mape of this species collecter at Columbia, S. C. [C. V. R. Coll.] Aletia xylina.-Many specimens bred from pupre of this species, from August 4 to September 10, 1879, and during subsequent autumus, receired from various southern States, especially Alabama and Texas. [C. V. R. and Dept. Agr. Coll.]

Desmia maculalis.-Missouri (no date). [C. V. R. Coll.]

Cacacia rosaceana (?).-OOne very small specimen bred June 12, 1873. [C. V. R. Coll.]

Gelechia galle-solidaginis.-Missouri (no date); a rery small specimen. [C. V. R. Coll.]

Botis alnialis Riley MSS. District of Columbia, October 8, 1883. [Dept. Agr. Coll.]

9 (2) Chalcis robusta Cresson.

This species was described by Mr. Cresson (Proc. Ent. Soc. Phila., iv, 1865, r. 101) from four Cuban specimens. There is one specimen in Professor Riley's collection which agrees perfectly with the description, and which was bred by Mr. Hubbard, September 14 or 15, 1S81, at Crescent City, Fla., from a cocoon of Lagoa opercularis. Mr. Hubbard, also, in June or July, 1Ss2, bred auother specimen of this insect from a chrysalis of Papilio cresphontes, also at Crescent City. The chalcid issued from a large circular hole ent through the thorax of the pupa. [Dept. Agr. Coll.]

\section{0. (3) Chalcis columbiana, u. sp.}

Female.-Length, $5^{\mathrm{mm}}$. Head and dorsum of thorax black, with whitish hairs and large close punctures; scape of antenne ferruginous; tegule, Jellowish-white; abdomen, ferruginous, with the last joint black, and the dorsum of the last five joints also black; front coxio black, middle and hind ferruginous; middle femora with a black central spot; hind femora ferruginous, with a jellow spot at tip; tibiæ with a sellow spot at either end. Wings hyaline, reins dark brown.

Described from 1 collected in District of Columbia July 10, 1880. [C. V. R. Coll.]

Comes near description of $C$. coloradensis Cress., but may be distin. guished by its ferruginous hind coxæ and basal abdominal joints.

\section{1. (4) Chalcis tachinæ, $\mathrm{n} . \mathrm{sp}$.}

Female -Length, $4.4^{\mathrm{mm}}$; expanse, $7.6^{\mathrm{mm}}$. This species comes close to C. coloradensis Cress. General color black; tegulie sellow; all legs ferruginous, except coxa ; midNle temora and tibise with a dusky baul in center; teeth of hind femora black; hind femora with a yellowish spot at apex; hind tibia with a blackish stripe ventrally. 
Described from 1 s specimen. This specinen was bred, December 29, 1383, from the puparium of a Tachinid, the larva of which was foumd with the egers of Caloptenus atlunis Riley, at Boscawen, X. H., Octuber 7, 1853. The Tachinid larva showed no signs of being infesterl, and transformed to an apparently healthy pupa. [C. V. R. Coll.]

\section{Genus Haltichella Spinola.}

Head triangular; eyes large. Antenute inserter contiguously, near the mouth: scape long, reaching to the ocelli. Anterior wings with a short marginal rein, very short stigmal and still shorier post-marginal. Abrlomen ovate, -econd se'gment somewhat tlattened above. Posterior femora smooth below, or obtusely bidentate. Posterior tibiæ with two spurs, middle with one.

12. (1) Haltichella americana, n. sp.

Female.-Length, $\mathfrak{q}^{\mathrm{rum}}$. Head and thorax densely and coarsels punctured, more closely on occiput. Color black, with whitish pile. Front coxie, and femora black, trbix fermginous at either end, tarsi ferruginons; middle legs the same: hind legs entirely black, tarsi ferruginous. Wings very slightly dusky under the stigma.

Described from 2 ' 's, both collected at Washington, D. C. [C. V. R. Coll.]

Approaches rery closely H. armata (Panz.) of Europe, but differs in the completely black antenuæ and the nearly clear wings.

\section{Sub family EXCYRTINA.}

The eight genera of this subfamily, which are represented in the collec. tions, may be separated as follows, the females alone being cousidered:

A. Scutellum with a tuft of stiff hairs at tip................... ChILONEctrus. B. Scntellnu with no such tuft.

a. Head with very deep, large, and regnlar round impressions.... Botmiotionax. b. Head with no such sculpture.

a. Head thickly and finely punctate, antennal club often obliquely truncate.

Cupidosoma.

b. Head nearly smooth, antennal club always strougly obliquely truncate.

c. Antennal club not obliquels truncate.

HoMALOTYLS. a. Mesonotum lusterless.......................................... bb. Mesonotum shining with a metallic lnster.

aa. Antenne extremely long and thin; vo marginal vein........ Psilopurys. $b b$. Antenna very long and thin; marginal vein longer than stigma.

LEPTOMASTIX. cc. Antennie not specially long .................................

In the Annual Report for 1850 I described twelve species of this sub. family, all of which were parasitic upon barli-lice. I here describe twenty-three additional species, but of these only eight are bark-louse parasites, three are parasitic upon P'sylliclie, five upon Lepidopterous larra, one upon a Coleupterous larva, and two upon I)ipterous larva, while the hosts of four are unknown. Of these four the strong probar. bilities are that one is parasitic upon some Dipterous larva, one upon a Lepidopterous, and the other two upon bark-lice. 


\section{Genus Copidosoma Ratzeburg.}

Female.-The antennæarise near the border of the mouth; the scape is long and slender; the six-jointed funicle long and slender, or short and comparatively thicker; theclnb is either long, delicately bent and somewhat rounded at tip, or it is thicker and markedly obliquely truucate. This truncation is produced hy the drying of a strip of mo:e delicate membrane upon one sideof the club. Front and rertex closely punctured, without larger deep punctures. The inesoscutum and often the scutellum have with most species a sculpture which was called by Ratzebnrg "schuppig" (scaley), and also a thicker punctuation with round or aciculate punctures. The marginal vein is either lacking, or it is a little shorter than the stigmal. The wings are hyaline. The ovipositor is very long, but may also be entirely hididen.

Male.-The male resembles the female in the form of the bods, in the punctuation, and also in the relative proportion of the wing veins, differing to a marked degree only in the antennæ. These are given off near the border of the mouth as with the female; thescape is long and slender, the pedicel shorter than the first funicle joint; the funicle is rather thickly covered with short hairs (the hairs shorter than the joints), with the joints separated above more than below ; the club is about as thick as the finicle. The base of the scutellum has a more or less delicate longitudinal carina, but no furrow.

\section{3. (1) Copidosoma gelechiæ n. sp.}

Female.-Len rth, 1.5 $5^{\mathrm{mm}}$; expanse, $3.5^{\mathrm{mm}}$; greatest width of fore wing, $0.65^{\mathrm{mm}}$; antennal club of the obliquely truncate type, as long as the five preceding funicle joints togrether; pelicel of the same length as the first funicle joint; funicle joints gradually decreasing in length from 1 to 6 . Punctures of head nearly romnd, of mesoscutum lengthened somewhat longitudinally, of the axilla transversel 5 aciculate towards tip, broader near base, of the scutellum longitudinally acienlate, especially narrow down the median line; ovipositor extruding but slightly; marginal vein wanting. Color: Head and pronotum, black, with purplish refiections; antenux, dark brown, nearly black throughont, end of pedicel yellowish; mesoscutum, bright golden green; axillæ, somewlit more subdued; mesoscutellum very dark brownishgreen, tegnlie of the same color; ahdomen smooth and shining with a greenish luster; all coxa dark green; front and middle legs entirely honey-yellow; hind femora dark greell, yellow at tip; hind tibia sellow, with a dark band around proximal third; tarsi yellow.

Male.-Length, $1.6^{\mathrm{mm}}$; expanse, 3.9 $\mathrm{mm}$; greatest wilth of fore wing, $0.79^{\mathrm{mm}}$. Antennal club but slightly longer than sixth funicle joint; pedicel nearly as thick as long; first funicle joint nearly three times as long as pedicel. Punctuation like that of $q$. Color: Head, pronotum, and mesoscutum all bright golden-green; axillæ and mesoscntellum, a shade less brilliant; all legs nearly black throughont, with a greenish luster, and with the knees jellowish; middle tibial spur and first tarsal joint also sellow; remainder of middle tarsi and all joints of fore and hind tarsi blackish.

Described from 4 's and 4 's's bred from the larvæ of Gelechia gallcesolidaginis collected in District of Columbia. The parasites issued October 19.

Variety a.-What may be ealled a rariety of this species was bred in great numbers by Mrs. Mary Treat from G. gallce-solidaginis, August 8, in New Hampshire. The female of this variety lacks the brownish. 
band on the hind tibix, and the male has wirler yellow bands at all the knees, and the tarsi are lighter in color.

Variety $b$. - In this variety the hind femora become entirely honeyyellow. Many specimens occur among those bred from $G$. gullicsolidaginis in Missonri; and an intermediate form, in which the hind femora have a blackish shade, also occurs anong the same lot of specimens.

It was this variety which was popularly described by Professor Riley in the first Missouri Entomological Report (p. 176) as "the Intlating Chaleis"; giring an acconnt of its habits, in which it does not differ from other members of the genus, except that, inasmuch as its host is a gall-inhabiter, it has to escape from the gall as well as from the inflated skin. All the iudiriduals, according to the report just mentioned, "escape through a single minute hole which must be made by one of their number"; but it has also been observed that where the host has already prepared the opening for its own future exit, before succumbing to the attacks of the parasites, the latter make use of this opening for their egress. [C. V. R. and Dept. Agr. Coll.]

\section{4. (2) Copidosoma vagum, n. sp.}

Female.-Length, $1.4^{\mathrm{mm}}$; expanse, 2. $\varepsilon^{\mathrm{mm}}$; greatest willth of fore wing, $0.46^{\mathrm{mm}}$. Club of antennæ delicately curvel, not obliquely truncate, as long as the two preceding funicle joints togetber. Punctures of head ronnd, of mesoscutuu and axillo nearly ronnd, somewbat polyhedral; of scutellum longitndinally aciculate; abdomen slightly transversely shagreened at base; ovipositor one-third as long as aludomen. Color: Antenne black, scape with metallic luster ; head and pronotnm dark and somewhat purplish; mesoscntum bright greenish; scutellum coppery; abdomen shining greenish-black; all coxie and femora shiuing black; frout and middle femora, sellowish at tip; all tibix sellow, middle and hind with a brown ring near base, and fore with a brownish shade above ; front and hind tarsi clusky; midtle tarsi and tibial spur light yellow.

Male.-Length and proportions about the same as with , exeept that the wings are somewhat longer and stronger. Club twice as long as sixtl funicle joint, first funicle joint twice as long as pedicel. Punctation as in $\$$; ablomen more strongly shagreened; mesoscutellum with a faint median longitudinal cariua ; colors as with the \&, except that the hind tibie are almost entirely black, aud the front tibia entirely brown; hind tarsi white, except last two joints.

Described from four $\$$ 's and many î' 's bred from the larræe of Gelechia pseudacaciella Chamber's, in Missouri in May. [C. V. R. Coll.]

15. (3) Copidosoma celænæ, n. sp.

Female.-Leugth, $0.93^{\text {mum }}$; expanse, $2.2 \mathrm{ymm}^{\mathrm{mm}}$; greatest width of fore wing, $0.33^{\text {mun }}$. Antennie, rather short; club of the obliquely truncate type; peclicel three times as long as first tumicle joint, which is thicker thin long; funcle joints increasing slightly in length, and iu ahout the same ratio in thickness ; chub as long as the tive preceding funicle joints together. Head and mesosentum with roundish poly hedral impressions, those on the head beconing some what elongate trans erersely towardsoceiput, and those on sentum longitudinally towards scutellnm: axille with the same, becoming transiersely aciculate towards tip; punctures of mesoscutellnu roumelish at immediate base, but longitudinally acieulate elsewhere. Color: Head, mesosentel, axillw and tegulo dark with a coppery luster; uesosentnu dark golden-green; anten- 
„w black, abdomen dark with a greenish luster, transversely shagreened above; all coxæ and femora black ; front and hind tibiæ dark brown, whitısh at base; middle tibise light brown, whitish at both base aud tip; front and hind tarsi yellow brown; middle tarsi whitish.

Described from many $\rho^{\prime}$ 's, no $\delta$ 's; bred, May 16, from the larva of $C e$ loena renigera, collected at Saint Louis, Mo. The parasited larra did not present the usual honercombed a ppearance, on account of its large size and tough brown skin. The parasites, too, are very small, and the minute punctures made in exit are almost imperceptible. On breaking the larra open, howerer, the honejcomb structure is at once apparent. [C. V. R. Coll.]

\section{6. (4) Copidosoma intermedium. n. sp.}

Female.-Length, $1.25^{\mathrm{mm}}$; expanse, $3.2^{\mathrm{mm}}$; greatest width of fore wing, $0.57_{\mathrm{mm}}$. Differs from C. gelechice in the following particulars: Punctures of mesoscutum only slightls elongated longitudinally behind; punctures of mesoscutel subaciculate longitudinally, but not so sharp as in gelechice; of axillæ, nearly round. Antennw, black ; front legs dark brown thronghout; middle legs with dark brown femora, a lightbrown shade near base of tilia ; most of ia, tibial spur, and tarsi light yellow ; hind legs with greenish femora, dark brown tibiæs yellow at t:p, and yellow tarsi.

Male.-Dimensions same as in female, except that the fore wing measures $0.6^{\mathrm{mm}}$ in width. Punctures of vertex with a transversely elongate tendency; of mesosentel even broader than those of 9 , narrower in center near base than elsewhere. Flagellum of antennæ strongly flattened; joint 1 of funicle, three times as long as pedicel, and considerably wider. In color differs from $q$ as follows: Antennæ; brown; scape darker than flagellum; head, pronotum, mesoscutellum, and axillø with a strong bluish-green luster; front and middle femora and tibiæ dark brown, with yellowish tips; hind femora and tibiæ nearly black, with greenish luster, yellow only at joints; front and hind tarsi brown, middle tarsi jellow.

Described from $2 \%$ 's and 25 's's bred, October 11, from the larræ of Gelechia galloc-asterella Kellicott, in galls collected at Vineland, N. J., by Mrs. Mary Treat; also bred in August from galls of the saine insect collected around Saint Louis. [O. V. R. Coll.]

\section{Genus Encyrtus Dalman.}

Female.-Antennæ 11-jointed, inserted not far from the sorder of the mouth, moderately thick, and, with the exception of the scape, very seldom compressed; the scape is often strongly broadened; the club is rounded, or with a slight oblique truncation at tip. The facial impression is rather large and often quite deep. The mesonotum is transversely arched, shagreened, and more or less lustrous; the scutellum shows a different sculpture. The wings are always developed and ciliated; the marginal vein is present, seldom very short; the stigmal is moderately long. The ovipositor is not as long as half the abdomen.

Male.-The flagellar joints are slightly or not at all compressed, and covered equally (not in half whorls) with hairs.

17. (1) Encyrtus sublestus, n. sp.

Male.-Length, $1.28^{\mathrm{mm}}$; wing expanse, $2.66^{\mathrm{mm}}$; greatest width of fore wing, $0.51^{\mathrm{mm}}$. Scape short, four times as long as thick; pedicel, at distal end, as thick as long; first flagellar joint, two and one-fourth times as long as pedicel; remaining flagellar 
oints snbeqnal, the third being the shortest; the (hnl) is nearly as long as the two precelling joints together; all joints, except seape and perlicel, furnisled with long non-whorled hairs. Head and mesomotum very delicately but distinctly punctures. Color: Head and thorax metallic blue-black, abdomen sling black; all coxae metallic blue-black; all femora brown, light at tips; all tibias dusky, light at tips, the hind tibia darker than the others; all tarsi pure white with dark claws. The stigmal vein is longer than the marginal, which is very short and thick.

Described from 1 ô specimen ( $q$ unknown) brel, $A$ pril 6, 1852, from Lecanium sp. on Pinus unstralis, collected at Archer, Fla. [U. V. R. Coll.]

\section{8. (2) Encyrtus ensifer, n. sp.}

Male.-Length, $0.66^{\mathrm{mm}}$; wing expanse, $1.75^{\mathrm{mm}}$; greatest brcalth of fore wing, $0.36 \mathrm{~mm}$. Antenua long and furnished with long hairs arranged in two irregnlar whorls; pedicel and flagellar joints subequal in length and about 1.5 times as longr as broad; the flagellar joints are deeply incised dorsally, givihg each a moderately strong, rounded, dorsal prominence; the clnb is somewhat louger than the two preceding flagellar joints. Head and mesonotum very delicately aud finely punctured. Color: Head, thorax, and abdomen shiny dark-brown, nearly black; antennis light brownish-yellow; all legs dusky, light at joints; wing-veins dusky, marginal vein darkest. Stigmal vein longer thau nıarginal, uncus consisting of four cells. [The penis, as shown in one specimen, is somewhat hastate and not bifid as with Eupelmus and other chalcids. ]

Female.-Length and proportions much the same as those of the $\delta$. Antennæ somewbat compressed; scape not widened; pedicel twice as long as wide and somewhat longer than first flagellar joint; all flagellar joints subequal in length and width aud flattened cylindrical in form; club large, oval, compressed laterally, as long as three preceding flagellar joints. Sheath of ovipositor more than half the length of abdomen. In every specimen examined the ovipositor was not contained in its sheath, but stretched ont from its insertion in the first ablominal joint in a sworl-like curve as long as the whole body. General color as with $\hat{\delta}$; base of antenual scape dusky. tip yellow, pedicel dusky thronghont, tlagellum light yellow-brown; legs slightly dusky, except at ends of joints; ovipositor bright yellow, sheath dark brown.

Described from $3 \hat{o}, 4$ s specimens, bred June 1 and j, 1ss2, from Aspidiotus corticrlis Riley MSS., on peach, collecterl at Crescent City, Fla., by H. G. Hubbard. [Dept. Agr. and C. V. R. Coll.]

\section{9. (3) Encyrtus fuscicornis, n. sp.}

Female-Length, 1.93mm ; wing expanse, $4.6^{\mathrm{mm}}$; greatest widtl of fore wing, 0.(6) Punctuation of mesonotnm very delieate. Antemul seape slender, not wilened. marginal vein present, but shorter than stigmal. General color dark honey-yellow; anteunal seapo dark yellow, pedicel and first three funiclo joints fuscons, last three funicle joints light yellow, club black and compressed ; sentellum duski and and with an irrdeseent tinge; tegnlau dnsky at tipss metanotum black; superior surace of ablomen black, inferior surfaco dusky, all legs miformly yellow. Wings fuseous, somowliat clear at base, and with two tramsverse lyaline streaks, the broader of the two, just at tip of stigna, with its proximal border concave and its distal border straight, aud the uarower one at outor third of wing with its two borders parallel.

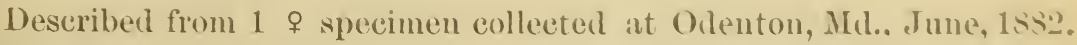
[C. V. R. Coll.] 
20. (4) Encyrtus puncticeps, n. sp.

Female.-Length, 2.2 $2^{\mathrm{mm}}$; expanse of wings $4.42^{\mathrm{mm}}$; greatest width of fore wing, $0.69 \mathrm{~mm}$. Scape, slender, not widened; pedicel, stout, conical; funicle joints, except first and second, wider than long, and the exceptions are but slightly longer in proportion to their width; club flattened, pointed at tip and very obliquely truncate from near base to tip. Head and face very thickly and finely punctulate; ocelli in a somewhat acute-angled triangle; mesonotum thickly and finely punctate. Color: Head dark reddish-lorown, scape and pedicel the same, funicle blackish, club black; margin of eyes black; pronotum dusky; mesonotum dark honey-yellow, with the scuto-scutellar furrow and the tips of scapulæ black; tegulæ light yellow, black at tips; metanotum and abdomen, black; frout, middle, and hind coxæ and femora and front and middle tibix, houey-yellow; hind tibiæ and tarsi metallic blue-black; middle tarsi, except basal half of first joint, black; front tarsi dusky. Wings byaline except a subcircular brown patch just beneath stigma; marginal vein lacking, postmarginal short.

Described from 2 ㅇ specimens collecter at Arlington, Va., September, 1881. [C. V. R. Coll.]

\section{1. (5) Encyrtus bucculatricis Howard.}

This species, which was described and figured in Lintner's first report as State entomologist of New York, was first bred by Professor Riley, in the spring of 1874, from the cocoons of Bucculatrix pomifoliella (collected at Allenton, Mo.), together with Cirrospilus flavicinctus Riley, a small Braconid and a minute Tetrastichid, the latter being probably a secondary parasite. The Encyrtus was by far the most numerous of these parasites, and was continually issuing from the latter part of March until the first week in July.

In July, 1854, it was bred from the cocoons of a Bucculatrix on oak on the Department grounds at Washington. From one to three of the parasites issued from a siugle cocoon. The species was originally described from the $q$ only, but among these last bred was one $\delta$. The male is somewhat smaller than the female, the tibiæe are dark brown in color, and the antennæ light brown. The joints of the flagellum are well separated and furnished with well-marked whorls of hair. [U. V. R. and Dept. Agr. Coll.]

\section{2. (6) Encyrtus trioziphagus, n. sp.}

Female.-Length, 1.3 $3^{\mathrm{mm}}$; wing expanse, $2.9^{\mathrm{mm}}$; greatest width of fore wing, $0.51^{\mathrm{mm}}$. Antenual scape stout, short, not reaching to top of the eyes, with no foliation below; pedicel short, conical, as thick as long and not exceeding in length the first funicle joiut; joints of funicle hard to distinguish, somewhat flattened and subequal in length, sixth as broad as long; club subfusiform, as long as three preceding funicle joints tngether. Anteunal groores deep; two slight nalar inipressions; clypeus and vertex covered with fiue punctures, lower face smooth, eyes wide apart; ocelli form a very obtuse angled triangle. Mesonotum delicately shagreened, with slight, sparse punctures, each giving rise to a short, delicate hair; no marked difference between scutum aud scutellum in punctuation; axillæ just meet at tips. Wings perfectly clear; marginal vein wanting; stigmal one-third longer than posturarginal. Abdomen nearly circular, sunken in center. Color: Flagellum of antennæ brown; scape and pedicel black, with a greenish luster; lower part of face with a brilliant purplish-blue luster; clypeus and vertex dark coppery-brown; pronotum, coppery; 
mesonotum brigbt shining green, the scutnm somewhat more brilliant than the scutellum; metanotum aud abdomen shining black, with a dark green luster; all coxw and femora dark green, honey-yellow at tips; front tibia honey-yellow, greenish at base; middle tibia entirely honey-yellow, sometimes with a slight green spot near base; hind tibiæ green, honer-yellow at either end ; front and hind tarsi brownish; micllle tarsi yellow.

Yale.-Length, $1^{\mathrm{mm}}$; wing expanse, $2.5^{\mathrm{mm}}$; greatest willth of fore $w i n g, 0.5^{\mathrm{mm}}$. Differs from of chiefly in the antenne. The flagellum is much flattened; scape still shorter than in $\$$ : pedicel very short and insignificant; joint 1 of the funicle twice as long as wide, and three times as long as pedicel; joints 2,3 , and 4 are fang-shaped dorsally; joint 3 more acute than 2 or 4 ; joints 5 and 6 resemble joint 1 in size and proportions; club short and suboval. Abdomen short and subcordate in form.

Described from 4 9 's and 2 i 's bred, November 7,1881 , from the galls of the Psyllid Trioza diospyri (Ashmead), on the P'ersimmon (Diospyros virginiana) on the Department grounds at Washington.

This species is markedly different from Encyrtus triozce André, bred by M. Ed. Audré from Trioza centranthi Vallot, aud described in Anu. Soc. Ent. France, 1878, p. 84 ; but belongs to the same group of the genus Encyrtus as $E$. strobili (L.), to which it is quite closely related. $E$. strobili, however, preys upon certain gall-making Cecidomyids, as Cec. rosaria and C. salicina.

A single Enerrtus issued from a single Trioza in every case, making its way through the dorsum of the abdomen of its host. [Dept. Agr. and C. V. R. Coll.]

23. (7) Incyrtus solus, n. sp.

This species also belongs to the group of $E$. strobili(L.), and does not differ structurally from $E$. trioziphagus to a material extent. In size aud coloration it does differ quite markedly.

Female.-Length, $2^{\mathrm{mm}}$; wing expanse, $4.2^{\mathrm{mm}}$; greatest width of fore wing, $0.7^{\mathrm{mm}}$. Mesonotum somewhat more deeply shagreened than with trioziphagus. Color: The basal portion of each antennal joint brown, distal portion honey-rellow; face black, with a faint bluish tinge; mesonotnm black, faintly greenish; abclomen shiny black. All legs entirely jellow, except hind coxie, which are black, with a greenish luster.

Described from 1 o specimen bred, IIarch 14, 1879, from the gall of Trioza magnolice (Ashmead), on Persea carolinense (Red Bay), collected at Gainesville, Fla. Its habits appear to be the same as those of the precediug species. [C. V. R. Coll.]

\section{4. (8) Encyrtus pachypsyllae, n. sp.}

This species is closely related to E. trioziphagus. The minute spines at the distal end of the posterior tibia, opposite the tibial spur, are longer and mere enrved than with trioziphagus. The coloration differs in that with pachypsylle the tibia and tarsi are all light honey-yellow, and the flagellum of the $\delta$ antema is light brown. The of antenna also citfiers firom that of trieziphayns in that joints 1,2, and $: 3$ of the funicle are fang-shaped instead of 2,3, and 4 . Tho dinensions on the arerage are tho same in both speecies, althongh pachypsyllar is quite variable in the $q$.

Described from many of and os spreimens bred, between May jo and 10, 1SSt, from galls of l'achypsylla celtidis-gemma Riles, collected in Sonthern Maryland. [Dept. Agr. and C. Y. R. Coll.] 
25. (9) Encyrtus cecidomyiæ, n. sp.

Female.-Length, $1.8^{\mathrm{mm}}$; expanse $3.84^{\mathrm{mm}}$; greatest width of fore wing, $0.72^{\mathrm{mm}}$. Comes closer, perhaps, to the European E. notodontce of Mayr than to any other species. The scape is nearly cylindrical; pedicel somewhat bulbous; funicle joints very gradually decreasing in length and increasing in width from joint 1 , which is one and one-half times as long as thick, to 6 , which is nearly as thick as long; the club is oval, much compressed, and as long as the three preceding funicle joints together. Head and notum very delicately and uniformly punctured, the punctation of the mesoscutum and scutellum identical. General color metallic-green, flagellum of the antennæ black, all tarsi brown, femero-tibial articnlation of frunt and middle legs, and distal tip of middle tibice and accompanying spur hones-yellow. Marginal rein wanting, stigmal a trifle longer than postmarginal.

Male.-Dimensions, punctation and coloration nearly the same as with $q$. Differs in the antennæ, the scape of which is very short and slightly emarginate beneath ; pedicel short, less than half the length of first funicle joint; funicle joints subequal in length, subovoid in shape, well separated, and clothed with moderately long hairs; club oral, as long as last two funicle joints together; club and funicle honey-5ellow, scape and pedicel black.

Described from many $\delta$ and $q$ specimens bred, April 12, 1884, from the galls of Cecidomyia salicis-siliqua Walsh, collected in Northern Virginia. [Dept. Agr. and C. V. R. Coll.]

\section{Genus Chiloneurus Westwood.}

Female.-Antenne given off near the border of the mouth, 11-jointed ; pedicel longer than the succeeding joint; the flagellum is cylindrical or somewhat flattened; club spindle-shaped or compressed. Vertex narrow; head and face not coarsely punctured. Mesothoracic scutum is covered with short, delicate, silver-white hairs, and the scutellum bears a tuft of long, black, stiff bristles. The ovipositor protrudes slightly. Marginal vein long; stigma and postmarginal very short.

Male.-Differs from the female principally in the antennæ; the pedicel is scarcely longer than thick; the succeeding joints to the club are long, slender, distinct, and, with the exception of the first, are each contracted in the middle, and are furnished above with two half whorls of long, diverging hairs; the club is not thicker than the preceding joint, and is shorter than the two preceding joints together. The hairs upon the scutellum are more scattered than in the $q$, and not gathered together in a tuft.

26. (1) Chiloneurus albicornis Howard.

A single female of this species was bred, May 7, 1883, from an undetermined species of Lecanium collected on Quercus uquatica, "wateroak," at Bluffton, S. C., by Dr. J. H. Mellichamp. [C. V. R. Coll.]

In a small collection of chalcids labeled by Wralker I find a Chilon eurus bearing the label $C$. elegans Dalm., which closely resembles $C$. al biconis, the only difference perceptible (perhaps ou account of the poor conclition of the specimen) being a darkening of the third and fourth funicle joints. The Walker specimen, however, differs radically from the description of elegans in Mayr's revision, and furnishes only another instance of the proverbial carelessness of the English author. 
27. (2) Chiloneurus dubius, n. sp.

Male.-Length, $1.05^{\mathrm{mm}}$; expanse, $2.5^{\mathrm{mm}}$; wilth of fore wing, $0.3 \gamma^{\mathrm{man}}$. Antennite light brown; face, honey-yellow, brownish towards vertex: pronotum, mesoscutum, and axillie black, with silvery-white hairs on promotum and scutum; axillat finely punctured ; mesos(ntellnu bright rist-rerl, with a loose tuft of black hairs at tip : abdonien black, with a coppery lnster: fore wiugs with a small dusky patch below stigma. Front and middle legs light yellowish throngbont; hiud lews black throughont, with the exception of a whitish femero-tibial articulation and the first three white tarsal joints.

Described from $4 \delta$ specimens, parasitic in all probability, on a species of Lecanium (probabls undescribed) from Scotch and Dwarf Mountain Pine, collected in 1874. at Lancaster, Wis., by A. W. Barber, and later at St. Louis. [C. Y. R. Coll.]

28. (3) Chiloneurus dactylopii, n. sp.

A large number of specimeus of a species of Chiloneurus was brer from a common "mealy bug" (Dactylopius destructor Comst.), on the garlen Pronia on the Agricultural Department gromnds. at Washington, late in November, 1884. It is impossible to distinguish the female of this species from that of the European $C$. formosus Boh., as I am in. formed by Dr. Mayr; but the males of the two species are readily dis. tinguishable by the relative leugths of the marginal and stigmal veins. In formosus the marginal is twice as long as the stigmal, while in dactylopii it is only slightly longer. [Dept. Agr. and C. V. R. Coll.]

\section{Genus Aphycus Mayr.}

Female.-Autennie 11-jointed, moderately short, iuserted near the month; scape widened or cylindrical; pedicel ahout twice as long as thick; the joints following the pelicel are thicker than long, and increase in thickness by degrees: the club is abont as long as the three precerling joints, and is obliquely ronuded, of ten compressed. Face, vertex, and dorsmu of thorax are lusterless aml fiuely punctate, frequently clothed with yellowish hair. Ovipositor nsually unt potnding. The marginal vein is not developed, and the stigmal is given off at the juncture of the smbmarginal with the costa.

Male.-Distingnished by the antenna, in which the pedicel is longer than the succeeding joint (this is so also with the female but not with the males of allied grenera). The flagellum is nuiformly elothed with hairs; the first joints are longer than thick, and the chll only so long as the two preceding joints.

\section{9. (1) Aphycus brunneus, 11. sp.}

Female.-Length, $1.06^{\circ m m}$ : expanse of wings, 2.12 mm ; greatest wilth of fore wings. $0.41^{\mathrm{mm}}$. Scape of antennie not broalened: ovipositor slightly exserted. Heal very delicately shagreened; mesosentmu, seipulie, and mesosentellum thickly bnt not deeply punetures: punctures of mesesentnm and scapulie transverse oral, and of ecutellnm longitulinal oval, "onverging toward the anterior angle; pusterior border of mesosentelhm smooth, as is also the metanotnm. General colur yellow-brown, vellow helow: seape and pediecl of antennie brown. Hagellan joiuts yellowish, eluh brown; all coxa brown; front femora, tibiat, and tarsi yellowish white. with a faint brownish patch on the dorsal side of femora and tibiar middle fomora and tibia (10)う一- 
yellowish white, each with a median brown aunulation, tarsi yellow; hind femora and tibice brown, white at base of femora and at base and tip of tibir, tarsi yellowish white; wing veins yellowish, dusky at origin of stigmal.

\section{Described from 1 s specimen ; î unknown.}

Bred, Norember, 1874. from specimens of Diaspis rosic received from Mrs. Mary Treat, Vineland, N. J. [C. V. R. Coll.]

30. (2) Aphycus ceroplastis, 11. sp.

Female.-Length, $1.4^{m m}$; expanse, $3.3^{\mathrm{mm}}$; greatest width of fore wing, $0.51^{\mathrm{mm}}$. Antennal scape with a slight expansion below near tip; club flattened, oval. Mesoscutellum with a slight longitudinal median impression; ovipositor well exserted; ocelli form an acute-angled triangle. Color: Autennal scape yellow, with a black stripe near base and another vear tip, including the expansion, aud broadest on the outside; basal half of pedicel black, distal half light yellow : funicle brownish at joint 1 , each joint growing lighter in color to joint 6 , which is yellow: clnb, dark brown, nearly black, sometimes lighter at tip; hear and face yellow, with a large brown spot on each cheek, occiput brown: pronotum black, mesosentum and axillie yellow, with a dusky shade towards the pronotal border of tbe mesoscutum ; mesoscutellum black, metanotum also black; tegnlae yellow, dusky at tip ; abdomen black above, yellowish beneath. especially near base; oviyositor yellow; the conspicuons shields at the sides of the hody (which mas possibly he homologized with the epimera of the mesothorax) are shiny black, yellow at bases; all legs yellowish : wings hyaline.

Male.-Length, $1.04^{\mathrm{mm}}$ : expanse, $2.4^{\mathrm{mm}}$; greatest width of fore wings, $0.42^{\mathrm{mrn}}$. Flagellum of antenne of a uniform light brown; brown spots on cheeks lacking; mesoscutum aud axillie black: hairs on the abdominal spiracles very couspicuons.

Variety a.-In four $₹$ 's the marked appearance of the mesonotum, produced hy the contrast of the yellow mesoscutum and axilla with the black mesoscutellnm and pronotum, was lost by a black shade in the middle of the mesosentum, and the axillæ were black as in the $\delta$.

Describel from 8 's, 2 s's, and 4 $q$ 's of variety $a$; all bred from scales of Ceroplastes artemesia Riles MSS., collected in 1879, ou Artemesia, at Silver City, N. Mex., by H. H. Ruslyy. The parasites issued in the latter part of March. [C. V. R. Coll.]

\section{1. (3) Aphycus maculipes, 11. sp.}

Female.-Length, $1.4^{\mathrm{mm}}$; wing expanse, $3.00^{\mathrm{mm}}$; greatest wid th of fore wing, $0.58^{\mathrm{mm}}$. In all respects, except in size and retails of coloration, similar to Aph. pulvinarice, Howard. The scape, which is greatly widened below, is shining black in color, with a white lrand at base and a white tip. Pedicel black, lighter towards the lateral portion of the tip. Joints $1,2,3$, and 4 of the funicle black, the inner surface of 4 sometimes lighter; elub dark brown. Face and front rust-red and hairless; ocelli coral-red, placed at the corners of an acute-angler triangle; occiput black nearly to the eyes. Anterior face of pronotum black with light yellow sides and a yellow transverse stripe dorsally; dorsal surface of pronotum of a pale bluish color. with whitish hairs, and furnisher at each angle with a distinct round black spot. Tegulie whitish, dusky at tip. Mesonotum fermginons; metanotum dnsky. Abromen blackish above, with a jellowish border. Venter uniformly light greenish-yellow; legs all yellowish; all tibixe with a donble row of rather small blackish spots above.

Male.-Length, $1.00^{\mathrm{mm}}$; wing expanse, $2.8^{\mathrm{mm}}$; greatest width of fore wing, $0.53^{\mathrm{mm}}$. Differs from the of principally in the antenne. In the $\delta$ antennx the leaf-like expansion of the scape is not so broad, and its white tip and base are more marked; the distal half of the pedicel is white, but the rest of the antennæ, inclnding flagellar joints 5 and 6 and the club, is of a nniform browu thickly clothed with short griseons hairs; the club is faintly yellowish at tip; and seen in certain lights, there is a yel- 
lowish tinge ou the ventral sides of joints is and $t$. The ablomen is very shom and its dorsum is black with an orange margin in which the black spiracles show very distinctly, each furnished with in few long black lacirs. The legs are semitraturarent, with the tibial spots not so strongly marked as in the fenule.

Describerl from "2 o's and 2 ' 's, bred May 7. 188.3. from a Leconium on the water-oak (Q. aquatica) collected at Bluffiton, S. C., by I)r. J. H. Mellichamp. The same Lecanium harbored Chiloneurus albicornis Howark, and occurs on Quercus laurifolia at Mobile, Ala., where it is parasited by Comys fusca Howard.

This species seems to be closely related to Aphycus punctipes (Dalm.), though the descriptious of the latter are too meager to form a definite idea of it. Certainly the colored tigure by Westwoor in Stephens's Illustrations of British Entomology (Supplement, Plate XLVI. Fig. 4) cannot be at all correct as to coloration.

Mr. Ashmead's Coccophagus annulipes should also be placer in this genus, and will prove closely related to this species, although I have as yet seen but one mutilated specimen.

Two females of what is probably only a variety of this species. having onlç the first funicle joint brown, are container in Dr. Rileš's collection, and are said to be parasitic on Attelabus bipustulatus. With our knowl. edge of the habits of the genus we can say with almost perfect certainț that these females rere not parasitic upon the Attelabus but upon some unnoticed Lecanium attached to the leaves of which the case of the beetle larra was made. [C. V. R. Coll.]

\section{Genus Bothriothorax Ratzeburg.}

Female.-The body is rather broad and flattened. The antenua arise not far from the border of the mouth; the scape is quite long and not flattented; the pedicel is as long as or longer than the first funicle joint; this last is as long as or louger than thick the club is shorter than the funicle or (with B.paradoxus) twice as long. The fince is delicately impressed; vertex and clspens are very broad, and the ocelli form a very obtuse-angled triangle. The thin (antero-posteriorly) broad (laterally) hear is rery deeply punctured, as are alsu mesonotum and scatellum; in the center of each puncture is a little papilla, from which springs a delicate little hair; besicles this, there is a leather-like sculpture. The mesonotum and scutellnu are rather strongly transverkely arched, and the lateral borders of the latter are quite sharp. The ovipositor is not at all, or very slightly, extended. The marginal vein of the hyaline wings is very short or is lacking; the stigmal is lomg and the postumarginal is short. or very short.

Male.-Very similar to the female and only distinguished by the antemie and by the sparser punctuation of the heal. The pedicel is short, somewhat longer than thick; the funicle quite exteuded, and the joints small and strongly arehed beneath, so that the funicle appears somewhat tonthed above; most of the joints laave two half whoris of long hair; the club is almost as long as the two last funicle joints together. 
32 (1) Bothriothorax virginiensis, n. sp.

Female-Length, $1.63^{\mathrm{mm}}$; wing expanse, $3.96^{\mathrm{mm}}$; greatest width of fore wing, $0.69^{\mathrm{mm}}$. Head rather wider than thorax; lower face densely rugose, but not densely punctulate; front and apex densely covered with large, shallow, round punctures; mesouotum punctured in a similar manner. Stigmal vein given off from submarginal just before it reaclies costa; postmarginal very short; antennse regularly clarate; the pedicel is longer than the first funicle joint, which is a little longer than broad; the remaining funicle joints increase in width and slightly in length; club slightly longer than fifth funicle joint. Color, metallic greenish-black; anteunæ jet black; all coxie metallic; all femora metallic, brownish at tip; front and middle tibiso brownish-yellow; hind tibie greenish-black; all tarsi, yellow.

Described from 1 \& specimen collected, September 18, 1881, at Arlington, Va. [U. V. R. Coll.]

The European Bothriothorax clavicornis is parasitic on the onion maggot, larra of Anthomyia ceparum, and hence, from the remarkable uniformity of habit in this subfamily, we should expect to find that $B$. virginiensis is parasitic upon some Anthomyia here. A. ceparum has not been fonnd to be parasited, however, in this country.

\section{3. (ध) Bothriothorax peculiaris, u. sp.}

Female.-Length, $1.75^{\mathrm{mm}}$; expanse, $4.25^{\mathrm{mm}}$; greatest width of fore wing, $0.7^{\mathrm{mm}}$. Antenue short, joints not well defined; scape not reaching to top of head; pedicel twice as long as thick, longer than first funicle joint; funicle joints subcylindrical, increasing in diameter from 1 to 6 : joint 6 as thick as long; club as long as the three preceding joints together, much flattened and sharply truncate at tip in a somewhat oblique line. Fore wings slightly ciliate at tip; hind tibia somewhat contpressed laterally; mesusentellum uniformly punctate. General color blue-green; basal half of antennal scape h-ney-yellow; distal half black above, sellowish below; flagellum black, clothed with short dense black hairs; front fernora black, with green luster, sellow at tip middie and hind femora holley-yellow; front and middle tibie honey-yellow; hind tibice black; all tarsi honey-yellow.

Hale.-Same size and proportions as $\$$. Antenna mnch longer and more slender than with $q$; pedicel twice as long as thick; joint 1 of funicle three times longer than thick and one-third longer thau pedicel; the rest of funicle joints snbequal in length, about as long as pedicel, well separated and increasing slightly in thickness. Club flattened, truncate, and nearly as long as the two preceding funicle joints together. In coluratiou similar to $q$, except that the antenne and front femora are honeyrellow throngliout.

Described from 3 \%'s and 10 o's.

These were all, with two mutilated specimens, bred in November from a single Syrphid larva found on an oak leaf at Arlington, Va. The larva was honeycombed, as are the hosts of Copidosoma, and all of the parasites issued through two holes cut apparently by two of the most enterprising individuals. [Dept. Agr. and C. V. R. Coll.]

The characters of Bothriothorax will have to be revised. Mayr has described the male of $B$. clavicornis only, and while he shows that the $\hat{o}$ anteunx of this species differ (1. 82), he rejects Foerster's statement that the club of the $\delta$ antenna has "eine schief gestutzte, fast heilförmige Gestalt," like the $q$. He says, however, that his varying speci- 
mens were incomplete in the an tennie and probably lacked the club, as the $\delta$ of $B$. peculiaris, resembling the rarying indiviluals in all other respects, have the club described by Foerster.

\section{Genus Psilophrys Masr.}

Female.-The very thin and very long antenne are given off from the neighlorhobd of the uouth; the long thin scape reaches nearly to the ocelli; the pedicel is usually more than double as long as thick; the long funicle is extremely thin and filiform and its segments are so closely joined that when the funicle is straight the points of division are very indistinct; the first joints are longer than the last; the first is about twice as long as the pedicel, and the sixth, which is the shortest, is still five times as long as thick; the club is slightly thicker than the funicle, and is longer than the sixth funicle joint, but is shorter than the fifth and sixth together; at the end it is obliquely truncate. The head is not thick (antero-posteriorly). but is long, for the cheeks are somewhat longer than the eyes; the head is not so hroarl as the thorax. The facial groove is narrow but long and extends up between the eyes as far as their middle; the small keel-shaped facial prominence extends as a delicate carina to the end of the facial groove. The front and rertex form a strong rounder angle and are quite broad. The ocelli form an obtuse-angled triangle, the posterior ocelli lying near the ejes and the sharply-cut occipital border. The thorax is strongly arched transrersely and from above appears almost barrel-shaped. The pronotum, mesonotum, scapulix, and scutellum are closely united; the mesonotum is large and as long as the strong transversely-arched triangular scutellnm; the points of the scapnlie ueet. The abdominal segments are snbequal in length, and the ovipositor protrudes slighty. Tho fore wings are not ciliate (in this respect differing from all other Encyrtince ex cept Bothriothorax schlechtendali), and when folded reach only a very little beyond the tip of the ovipositor; the stigmal vein is quite long and arises from the juncture of the submarginal with the costa; the marginal is therefore not developed and the postmarginal is short.

Male. - Very like the female, with a smaller head, very delicately ciliate fore wings. aud much thicker, shorter, and differently formed antemue. The pedicel is onl s slightly longer than thick; the funicle is thick and clothed with short lairs (although louger than with the female); the first funicle joint is also the longest and the sixth the shortest, but this last is only donhlo as long as thick (the funicle joints nsually shrink so much after death that they appear compressed); the club is longer than the tirst funicle joint, and as thick at its base, gradually more sleuder, with a romuled summit. The first abdominal segment is longer than any of the others.

34. (1) Psilophrys hyalinipennis, u. s1).

- Male.-Length, 1.51min ; expause of wings, 3.0.2mm ; greatest width of tore wing, $0.6 \sigma^{\mathrm{mm}}$. Resembles mnch Ps. lonficornis (Walk.), of Enrope, but ditters markelly in the clear transparent wings. Color, metallic bluish-green, abdomen shing black, antennæ brown; all coxie metallie, all femora and tibie dark brown, with redlishyellow knees; tarsi, reddish-yellow, with black terminal joints: wing reins strong. dark browu in color.

Described from 1 ô specimen. Habitat, Missouri. [C. V. R. Coll. 


\section{Genus Homalotylus Mayr.}

Female.-The antenna are given off near the border of the mouth; the pedicel is somewhat longer than the first funicle joint; the 6 -jointed funicle has cylindrical joints, which increase more or less in thickness toward the club; the club is obliquely truncat,e from the tip to the base, or nearly to the base. The head is thin (fronto-occipitally): the facial groove is very delicate or is wanting (H. flaninius). The eyes are much farther apart below than above. The ocelli form an acute or a right-angled triangle. The face, and especially the clypeus, not broad, covered with very fine and thick punctulations, and with larger punctures in rows or irregularly placed. Mesonotum finely shagreened and moderately shining. The axillæ meet only in a point, or are far apart. The ovipositor is hidden. The hind femora have a longitudinal groove for the reception of the hind tibix. The marginal vein is very short, or is wanting. The stigmal is rather long.

Male unknown.

\section{5. (1) Homalotylus obscurus, n. sp.}

Female.-Length, $1.86^{\mathrm{mm}}$; wing expanse, $3.8^{\mathrm{mm}}$; greatest width of fore wing, $0.58 \mathrm{~mm}$. Antennal scape, very long and slender; pedicel somewhat more than twice as long as thick; first funicle joint one-third longer than thick; sixth funicle joint a trifle thicker than long; all funicle joints cylindrical, and increasing slightly in thickness and decreasing in length from joint 1 to joint 6 ; club as long as the preceding three joints together, obliquely truncate from tip quite to base. Facial groove entirely wanting. Ocelli form an acute-angled triangle. The larger punctures of the head are irregularly placed. The axillæ meet at their apices only. First joint of niddle tarsus as long as all the succeeding joints together, and only slightly incrassated ; middle tibial spur stout, and longer than the first tarsal joint. Color: Antennal scape, pedicel, and funicle black, club yellowish-white; face vellow-brown, with a metallic luster behind the ejes; pronotum and mesoscutum black, with a faint golden luster; mesoscutellum and axilla dead-black, owing to the very close fine punctures; tegulæ black at tips, brown at bases; metanotum and dorsum of abdomen black; venter of thorax dark honey-yellow, of abdomen black; all coxa and femora dark brown; all tibs black; front and hind tarsi black; middle tarsi, except fifth joint and middle tibial spur, white or yellowish-white. Fore wing with a large subcircular dusky spot in the middle, including stigmal and marginal veins, and with a narrow, clear, hairless streak extending transversely and proximally from marginal vein to near the hinder border of the wing; cilia very short.

Described from 13 specimens bred from Coccinellid larvæ, in all probability those of Cycloneda sanguinea L., at Centreville, Fla., by Mr. H. G. Hubbard. From two to five of the parasites were bred from each of the parasited larva. [C. V. R. Coll.]

Of the three European species of Homalotylus, the only one whose habits are known, $H$. flaminius (Dalman), lives in Coccinellid larvæ; and Walker (Entom. Mag. V, 1838, p. 54) states that he has bred it from Galeruca calmariensis, an insect which, though very abundant, has never been found parasited in this country.

\section{Genus Leptomastix Förstel.}

Female.-The antennis are very long, as long as or somewhat longer than the body, slender and clothed with short hairs; the pedicel is twice as long as thick; each of 
the three first funicle joints is about donble the length of the pedicel, and the three following decrease in length until the sixth is scarcely twice as long as thick; the clnb is slightly broaler than the funicle, is rounder on the end, and is as long as the last two funicle joints together. The facial impression is small, and the forehead extends ne ar ! the lower end of the eyes; the vertex is broal, and the ocelli are at the corners of an equilateral tria' '. l,oth clypus and vertex are vers tinely punctured. The thorax is moderately arched, the mesonotum somewhat shining and finely shagreened with sparse hair follicles; the scapula meet in the middle and form a very short longitudinal carina : the triangular, finels wrinkled scut ellum has rather sharp side borders and apex. The upper side of the abdomen is very delicately punctured and the segments are difficult to distinguish: seen from the side they appear subequal in length. The marginal vein of the fore wing is somewhat longer than the stignal, which is nearly equal in length to the postmarginal. The ovipositor is usually considerably protruded. The legs are longer than usual, and the middle tibial spur is very strong and prominent.

Male.-The male is to be principally distinguished by its antennie, which are cousiderably longer than the whole body. The relative proportion of the joints is about the same as in the female, except that the pedicel is very conical and only about as long as thick; the funicle joints are well separated by dorsal incisions. and each is very slightly constricted in the middle abore; the funicle is furnished with a number of long hairs, which are not arranged in whorls.

This striking genus was founded by Förster in 1852, and in the characterization of the female I have followed Mayr quite closely. Dr. Mayr, howerer, had before him but one specimen ( $q$ ), and as my material is extensive, I have made one or two changes. I have added a description of the male which was unknown to both Förster and Mayr. The geuus was founded on antennal characters, but mar be recognized at a glance from the length and strength of the middle legs.

\section{6. (1) Leptomastix dactylopii, n. sp.}

Female.- Length, $1.51^{\mathrm{mm}}$; expanse, $3.6^{\mathrm{mm}}$; greatest width of fore wing, $0.6^{\mathrm{mm}}$. General color honey-jellow, with a slight reddish tinge on the mesonotum; eyes, antennie (with the exception of a slight veutral yellow streak), occiput, immediately behiud the eyes, black; metascutum, posterior margin of pronotum, dorsum of abdomen, dorsal surface of posterior femora, more or less dusky.

Male.-Length, $0.97^{\mathrm{mm}}$; expanse, $2.65^{\mathrm{mm}}$; greatest width of fore wing. $0.46^{\mathrm{mm}}$. In effect darker than female, and quite variable in the amount of black with which the dorsum of the thorax is ornamented. The mesoscutum is always rellow, but tho scapulie are often very dark and the mesoscutellnm lias often a dark median stripe; the hind tibie and tarsi are also tlark.

This species is described from many specine'ns of both sexes bred in October and November, 1854, from Dactylopius destructor Comst., infest. ing Preonia on the Department grounds at Washington, D. C., in com. pany with Chiloneurus ductylopii. It is very similar to Leptomastix his. trio, judging from Mayr's description of the latter, and the difference may arise from the fact that histrio was described from a single speci. 
men, while the specimens which I hare show considerable colorational rariation. *

The appearance of this parasite upon the destructive mealy bug is to be welcomed. A large colony of the latter insect was completely destroyed by this Leptomastix and the Chiloneurus just mentioned. It is possible that both are recent introductions; at all events, neither bas ever been bred from Dactylopius here before, and we shall watch for them another season with interest.

\section{Subfamily APHELININA.}

The two genera mentioned under this subfamily may be separated as follows :

A. Fore wings with a hairless line extending from stigma transversely towards base

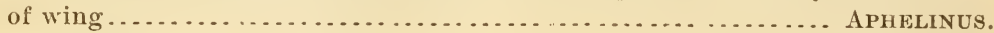

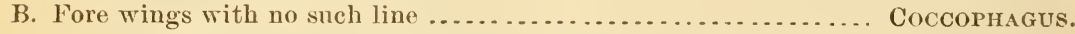

\section{Gemus Cocrophagus Westwood.}

Antenue 8-jointed; scape rather short and stout; pedicel one-third the length of scape and of about the same thickness; joints 3,4 , and 5 increase very slightly or not at all in thickness and decrease in length; club very plainly 3 -jointed, a little longer than the preceding two joints. Mesoscutum large, its postcrior broader, with a slight re-entering angle; sutures between parapsides aud scapulie very oblique. Mesosentellum nearly as long as broad, rounded behind, the fore part forming three sides of a hexagon, the side bordering on the scutnm a little shorter than the other two ; wings equally bairy, except at base ; no hairless line. Stigma small, but plainly visible, subtriangular in form. Middle tibial spur usnally not as long as first tarsal joint, often curved. Species usually of somber colors, often of two contrasting colors, black and yellow.

37. (1) Coccophagus vividus, n. sp.

Female.-Length, $1.03^{\mathrm{mm}}$; .wing expanse, $1.96^{\mathrm{mm}}$; greatest width of fore wing, $0.35^{\mathrm{mm}}$. General color shiny black; anteunie light brown, with the customary dark brown longitudinal carince ; greater part of mesoscutellum and visible portion of metascutellum bright orange-yellow, the line of juncture of the two colors on the mesoscntellum slightly irregular but not curved; tegulæ yellow; all coxse and femora brown, yellow at joints; all tibre and tarsi yellow, occasionally a dusky patch near base of hind tibse, and the fifth tarsal joint is of course brown. Entire mesonotum finely punctate.

Male.-Length, $0.55^{\mathrm{mm}}$; wing expanse, $1.47^{\mathrm{mm}}$; greatest width of fore wing, $0.25 \mathrm{~mm}$. Color as in female, except that the tegulie are brown and the scutellar spot is dull lemou-yellow, as large proportionally as in $\$$, but not so vivid.

Described from $1 \delta$ and 3 \%'s bred from Lecanium hesperidum on orrange, Crescent City, Fla., by H. G. Hubbard. [Dept. Agr. Coll.]

* Since the above was written I have received from Dr. Mayr the following concerning this species:

"Was nun Ihre letzte Sendung betrifft, so steht Ihr Leptomastix Dactylopii der europäiscinen Art sehr nahe, und wenn Ihre Exemplare nicht etwa durch unnatiirliche Verhältnisse der Zucht im Zimmer besonders klein nnd nuentwickelt geblieben sind, so kann Ihr Leptomastix ganz gut als eigene Art betrachtet werden, wenn auch die Unterschiede nur in der Grösse und Farbung vorhanden sind." 
38. (2) Coccophagus flavifrons, u. sp).

Male.-Length, $1^{\mathrm{mns}}$; wing expanse, $2^{\mathrm{mm}}$; greatest wielth of fore wing, $0.35^{\mathrm{mm}}$. Color: Eyes, clypeus, occiput, abdomen, and dorsun of thorax black, with a pronounced bluish-metallic luster on abrlomen; face, antennal scape, all legs, except hind tiba, lemon-yellow; flagellnm of antennir brown; tegulas orange-yellow; hind tibe brown, with yellowish extremeties; wing veins fuscons.

Described from 1. o specimen ; 9 unknown ; bred, April 6, 1882, from Lecanium sp. on Pinus australis, collected at Archer, Fla. Two other $\delta$ specimens, nearly agreeing with this species, but each lacking the head are in the collection. [C. V. R. Coll.]

39. (3) Coccophagus cognatus Howard.

One $\delta$ and 1 of this species were bred, April 2, 1881, from Lecanium sp. upon leaves of Melia azederach, collected by Mr. G. W. Latimer, at Eufaula, Ala. [C. V. R. Coll.]

40. (4) Coccophagus koebelei, n. sp.

Male.-Length, $0.84^{\mathrm{mm}}$; wing expanse, $1.59^{\mathrm{mm}}$; greatest wilth of fore wing, $0.34^{\mathrm{mm}}$. Color: Eyes, head, face, tegulæ, all thorax (except tips of meso and metascutelli), and abdomen shiny black; antenne light brown, scapd black; all tibix, tarsi (except last joint), and tips of femora lemon-yellow; all tibæ, except at tips, black; tips of meso and metascutelli orange-yellow; the line between the black and the yellow sharp and distinct, and convex posteriorly.

Described from $1 \delta$ specimen; $\&$ unknown; bred, April 6, 1882, froin Lecanium sp. on Pinus australis, collected at Archer, Fla., by Mr. A. Koebele, to whom the species is dedicated. [U. V. R. Coll.]

\section{Genus Aphelinus Dalman.}

Autenne 8-jointed; scape long and slemler; pedicel large, subconical: joints 3 and 4 very small: joint 5 as long as pedicel, subcylindrical; club large, with several minute bristles at tip. Mesoscutum wider than long: parapsides distinctly separated, small. Nesoscutellum very broad and short; subfinsiform, unicolorous. Middle tibial spur slender, as long as first tarsal joint. Fore wingseach with an oblique hairless line extending from the stigma backwards to the posterior border of the wing. Stigma small and inconspienous, club-shaped, romuded at tip. Species generally unicolorous, either vellow or blackish, rery seldom metallie.

41. (1) Aphelinus diaspidis Howard.

Nine females of this species were bred from a Mytilaspis on an Orehid, an undetermined species of Dycaste from Japan; receired February 6 , 187t, from Mr. George Thurber, of the American Agriculturist. [C. V. R. Coll.]

42. (2) Aphelinus mali (Halienan.)

Three 's of this species were bred at Washington, February $S$ and 15, 1879, from Schizoneura lanigera Hausm. [C. V. R. Coll.] 
The two genera mentioned under this subfamily may be separated as follows :

A. Posterior tibiæ with two spurs

EUPLECTRUS.

B. Posterior tibiæ one-spurred

Etachistus.

\section{Genus Euplectrus Westwood.}

Head triangular; eyes prominent. Antenuæ inserted below middle of face; scape long; funicle 4-jointed. Thorax highly developed; mesouotum with a median longitudinal carina. Abdomen with a moderate, cylindrical petiole. Posterior tibix with two very long spurs. Body not metallic, but of dark color; head and thorax with sparse, coarse hairs.

\section{3. (1) Euplectrus comstockii Howard.}

Male.-Length, $1.98^{\mathrm{mm}}$; wing expanse, $4.3^{\mathrm{mm}}$; greatest width of fore wing, $0.8^{\mathrm{mm}}$. Face triangular, narrowing sharply below eyes, smooth and glistening, witl a very few punctures; antennal scape slender, not widened. Pronotum very rugose, except at posterior border; mesoscutum somewhat transversely rugose, with a stronglymarked median longitudinal carina; mesoscutellum smooth; metathoracic carina very pronounced and dividing posteriorly; metatibial spine nearly as long as first two tarsal joints. Abdomen broadening from base and subtruncate at tip. General color shining black with long stiff whitish hairs scattered over thorax; labrum honey-yellow; antennal scape light ho:sey yellow, flagellum gradually darker, club quite dark : t tip ; all legs honey-5ellow; abdomen with a dorsal yellow spot eitirely bounded with black aud of an irregnlar pyramidal shape, the base of the pyramid towards tip of abdomen; venter yellow-brown along median line

Female.-Slightly larger; abdomen more nearly ovate.

Described from many $\hat{o} q$ specimens bred from half-grown larvæ of Aletia xylina (Say) in Mississippi, Alabama, and Florida. [C. V. P. and Dept. Agr. Coll.]

(See Report Department of Agriculture, 1880, Plate II, Fig. 4. See also Can. Ent., XII, p. 159, and Am. Naturalist, 1881, p. 16.)

\section{4. (2) Euplectrus leucotrophis, n. sp.}

Male.-Length, 1.25 $\mathrm{mm}$; wing expanse, $2.91^{\mathrm{mm}}$; greatest width of fore wing, $0.58^{\mathrm{mm}}$. Differs from $E$. comstockii in the following points: Mesoscutum very rugose; median carina scarcely visible; face, below eyes, and scape of antenn:e nearly white, slightly yellowish; all legs, including coxie, semi-transparent, whitish in color; the dorsal abdominal yellow spot extends to pedicel, and at its base widens ont to include the lateral borders of the abdomen; the venter is rellowish near base; elsewhere dark brown, nearly black.

Described from 3 ô specimens bred from unknown Arctiid larva, July 19, 1880, received from Dr. R. S. Turner, Fort George, Fla. [Dept. Agr. Coll.]

\section{5. (3) Euplectrus platyhypenæ, n. sp.}

Female.-Length, $1.67^{\mathrm{mm}}$; wing expanse, $3.8^{\mathrm{mm}}$; greatest width of fore wing, $0.6^{\mathrm{mm}}$. Differs from $E$. comstockii as follows: Pronotum markedly shagreened; mesosc 1tum only slightly roughened; median carina distinctly visible; hind border of abdomen well rounded. Color: Face entirely black; legs dark honey-yellow; hind coxse 
qnite dark at hases; yellow blotch on dorsum of aldomen, occupying nearly its whole surface, leaving only a narrow band of black around the edge ; venter the same.

Male.-Rather smaller than the + , but agrees otherwise, except that the scape of the antennix has a ventral leaf-like expansion; the abdomen is even more ronuded than in the of, and the yellow bloteb is much smaller.

Describel from 1 o and 1 \& bred, July 11, 1882, from the larva of Platyhypena scabra (F.), District of Columbia. [C. V. R. C'oll.]

\section{6. (4) Euplectrus catocalæ, n. sp.}

Length, 2.3 $3^{\mathrm{mm}}$; expanse of wings, $4.3^{\mathrm{mm}}$; greatest widtl of fore wing, $0.7^{\mathrm{mmm}}$. Differs from $E$. comstockii in its larger size, more rounded abdomen, and in the appearance of the abdominal blotch. This in the $\delta$ occupies the whole of the anterior half of the dorsum of the abdomen, while the venter is entirely yellow except at tip. With the $q$ the spot occupies the anterior center of the dorsim of the abdomen, is oval in form, and is bounded on all sides by a broad margin of dark brown; the venter is as with the $\delta$. The metascutellum is finely striated longitudinally. The yellow spot on the lower front extends to the base of the antennie.

Described from 3 ô's and 2 $q$ 's bred, July 5,1873 , from the larva of a species of Catocala at Saint Louis, Mo. [C. V. R. Coll.] This species has also been bred from a geometrid larva on birch, found at Hyatts. ville, Md., July 9, 1882. [.Dept. Agr. Coll.]

\section{7. (5) Euplectrus frontalis, 11. sp.}

Female.-Length, $2^{\mathrm{mm}}$; wing expanse, $4.7^{\mathrm{mm}}$; greatest wirlth of fore wing, $0.81^{\mathrm{mm}}$. In this species the sculpture of the thorax is nore definite than in any other so far considered. The pronotum is deeply but sparsely pnuctuate except at its posterior border; the mesoscutum is quite coarsely shagreened, and its median cariua is faint: the metascutellum is plainly lougitudinally striate. The yellow spot of the lower front includes the bases of the antennae, but the cheeks below this point are black to the bases of the mandibles. In otler respects it resembles E. catocala.

Described from 1 \&, bred, September 13, 188\%, from an unknown noctuid larva on walnut, collected at Arlington, Va. [C. V. R. Coll.]

\section{Genus Elachistus Spinola.}

Antemne inserted considerably below the midlle of the fice, flagellum very rarely incrassate; funicle 4-jointed; club 2-jointed. Thorax with a large conico-seniglebose pronotum : mesoscutum slort; mesoseutellum with bwo longitulinal grovres, meeting at the apex; netanotal metian carina acnte. Fore wings with the postmingiual vein plainly longer than the stigmal; stigual club small but with an acnte nuens. Abdomen nsually with a slort smooth petiole. Posterior tibie 1-spurred. Budy black, immaculate: hearl always more or less metallic.

\section{8. (1.) Elachistus proteoteratis, 11. sp.}

Female.-Length, $1.86^{\text {mmu }}$; wing expanse, $3.12^{\mathrm{mm}}$; greatest width of lore wing $0.53^{\mathrm{mm}}$. Head broally oval, checks well rounded, anteunal fossie eonvorging dorsally: the sutures of the mesoscutar parapsides and of the seapulie are continuons; the postmarginal vein is rather longer than the stigmal, which is very straiglit, with a small elub and a sharp claw. Face smootlı; oceiput and top of head near oyes slightly punctulate; pronotmm sparsely punctured, except at its smooth posterior boriler: mesosentun transversely shagreenod: mesosentelhum rery tiuely ooriaceons: meta and post- 
scutelli smooth; metathoracic carina delicate; petiole rather short, cylindrical, and rugose ; abdomen elliptical, concave above, convex below. Pronotum and mesoscutum with many white hairs; a longitudiual row of long delicate white hairs on the metapleura of each side. Color, dark metallic-green; scape of antenuse nearly white, flagellum, light ochre-yellow; mouth parts nearly white, mandibles shining brown at tips; all legs sellowish-white, except hind coxw, which are brownish near base; basal half of abdomen above with a bright straw-colored blotch, bounded by brown and ending posteriorly in a straight transverse line; venter of abdomen witk a longitudinal hones-sellow stripe, wider anteriorls than posteriorly.

Described from 3 ' 's bred, in June, 1873, from larræ of Proteoteras asculana Riles, at Kirkwood, Mo. [C. V. R. Coll.]

\section{9. (2) Elachistus cacœciæ, n. sp.}

Male.-Length, $1.93^{\mathrm{mm}}$; wing expanse, $3.84^{\mathrm{mm}}$; greatest width of fore wing, $0.74^{\mathrm{mm}}$. Face subtriangular, cheeks nearly straight; mesoscutar and scutellar furrows not contiunons, interrupted by the angle of the scapule ; postmarginal vein much longer than stigmal. Head aul eyes quite thickly covered with short, fine, dusky hairs, pronot um and mesoscutum furnished with longer and stouter dark hairs. Head sparsely punctured with trausverse oblique lines ou vertex and clypeus; occiput very finely and thickls punctured; scutellnm smooth, and mesoscutum only slightly shagreened. Color shining black, not metallic; scape of antenne whitish below, dark brown above, flagellum dark brown, with short, dense, whitish hairs; mandibles light reddish-brown; all legs yellowish-white, hind coxæ slightly darker at base; first two joints of abdomen above with a yellowish-brown spot extending nearly to lateral edges, venter light brown at base.

Described from 6 o's bred, August, 1877, from the leaf curl of $\mathrm{Ca}$ caecia rosaceana (Harr.), at Kirkwoud, Mo. [C. V. R. Coll.] One q specimen of appareutly the same species was bred at Washington, from Hyphantria textor, upon which it fed externally. The adult inade its appearance October 29, 1881. [Dept. Agr. Coll.]

\section{0. (3) Elachistus coxalis, n. sp.}

Female.-Length, 2.21 $\mathrm{mm}$; wing expanse, $4.34^{\mathrm{mm}}$; greatest width of fore wing, $0.7 \mathrm{~mm}$. Resembles E. proteoteratis rery closely, but differs in size, as just indicated, and also presents the following colorational differences: The posterior coxæ have upon their outer basal portion a large definite metallic-green spot, which in proteoteratis is only faintly indicated; the middle coxie are also faintly green at base; superior surface of antennal pedicel tinged with dark brown, superior portion of all the flagellar joints darker than inferior surface; metaplenral hairs long and conspicuons; ventral yellow stripe very narrow near tip of abdomen.

Described from 1 \& caught on window at Washington, D. C., Janu$\operatorname{ary} 14,1881$. [C. V. R. Coll.]

\section{Subfamily ELASMIN E.}

Head subglobose: front sparingly but strongly punctate. Funicle of antenuæ 3-jointed. Thorax : Pronotum short, parapsides not distinguishable, mesoscutellum depressed, metascutellum membraneous white. Wings narrow, marginal vein loug, stigmal very short, almost punctiform, postmarginal distinct. Abdomen sessile, with a compressed venter. Legs becoming gradually longer and stronger; posterior coxæ very large, tibiæ 2-spurred at tip. Antenna of the male with three branches. 


\section{Genus Elasmus Westwood.}

Head, antero-posteriorly rather narrow, vertex subacnte, eyes suboval, ocelli placed in a triangle. Antemne inserted below the middle of the face, scape not raching to ocelli, flagellum not incrassate. Thorax with obsolete punctures, sutures of the scutellum delicate, metathorax with uo (ariua, apex not perpendicular. Costa of the wings shorter than the marginal, costal cell very uarow. Abdonen triangnlar, terebra scarcely observable. Posterior tibix spinous underneath. Mesostermm smooth. Epistoma not distingnishahle, (p) pmera nearly triangular. Body black, metallic above.

Thomson in his remarks after the generic diagnosis of Elasmus says, "Arterna lefva parasitiskt pă Microgaster"-a general statement. hatzeburg, however, gives Aneure rhipiccros Först. as parasitic on Psyche graminella; Giraud gires E. flabellatus Westw., as parasitic on the same species and on Epichnopteryx leeli.x, and E. nudus Nees, as destroying Cecidomyia rosaria. Of the following species all are represented in notes as having been bred from Tineid larvæ except $E$. albicoxa, which was found in a jar with the eggs of Limnitis dissippus, from which it could not possibly have come. Microgasters were bred from the young larræ of $L$. dissippus, and, in default of careful notes, it is very possible that the specimen of E. albicoxa may have come from one of the Microgaster cocoons. In the same way Microgasters were bred from the Tineids on Rhus and Apple, from which E. varius and E.pullatus are stated in the notes to have been bred, and the mere entry in the note-book will not weigl against a unity of habit in the genus if such ean be shown to be probable. Thomson does not give his data, but the fact that Microgasters were bred in the cases mentioned would have seemed to afford a strong probability of such an unity of habit, had it not been that the last species of the genus, $E$. tischerice, was bred under ny eyes, and watched with the desire to determine this point in mind. Not only was no Mi crogaster observed, but the Elasmus larva was several times found feeding externally, just prior to pupation, upon the larre of the Tischeria. This observation will transfer Elasmus from the ranks of injurious in. sects to those of beneficial.

\section{1. (1) Elasmus varius, II. sp.}

Wale.-Length, $1.75^{\mathrm{mm}}$; wing expanse, $3.30^{\mathrm{mm}}$; yreatest width of fore wing, $0.33^{\mathrm{mm}}$. Head coarsely and densely punctate, the impressions more sparse upon the face. Mesonotum covered with long delicate hans, and appearing as if covered with minute overlapping scales. Sentellnm apparently smooth, hut, muler a high power, covered with fime wavy lines, and fumished near base with hairs. Ahdomen long, slender, acmuninate, furnished at tip with a mumber of stift black bairs. General color shining black; romded tip of metasentellum orange-yellow: metasentellar alpremelage menbranous white, rest of metanotnm metallic-green; first ablominal joint dorsally, striped with two transverse shaded bands of oche-yellew: venter of abdumen wehre-yel. low except at tip; frout eoxa blackat base, rematinder brownish-yellew: femora brown-

* "Das schildehen hat an der spitze cinen häutigen, drieckigen, ziemulich schavl z.n-

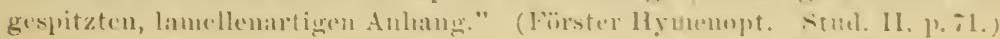


ish-yellow, shaded dorsally with brown; tibie yellow; tarsi fuscons; middle coxse black at base, rest brownish-yellow; femora black with metallic luster, and with a ventral lungitndinal yellow line; tibiæ jellowish, with a dorsal dnsky streak; tarsi dark fuscous; hind coxæ and femora shining black, light at joints; tibie dirty yellow, lined dorsally with brown; tarsi blackish; anteuna black with light hairs ; wing veins dark brown.

Described from 4 os specimens ( + unknown) bred, July 20, 1872, at Saint Louis, Mo., from the leaf curl of a miner and roller on Rhus copal. lina, probably Gracillaria rhoifoliella Cham. [C. V. R. Coll.]

\section{2. (2) Elasmus nigripes, n. sp.}

Male. -Length, $1.58 \mathrm{~mm}$; wing expanse, $2.91^{\mathrm{mm}}$; greatest width of fore wing, $0.27^{\mathrm{mm}}$. Differs from $E$. rarius in size and relative width of fore wing. The scutellar spot is small and narrow, and is not of so rivid an orange color as in E. varius. The front coxæ are black, femora and tibi:e earthy sellow, with many black hairs, which on the femora obseure the real color: tarsi dnsky; middle and hind coxe, femora, tibix and tarsi nearly black.

Described from 1 o ( $f$ unknown) bred, from Lithocolletis gregariella Murtfeldt, at Kirkwood, Mo., by Miss Murtfeldt, 18s1. [C. V. R. Coll.]

\section{3. (3) Elasmus albicoxa, n. sp.}

Mrale.-Length, $2.00^{\mathrm{mm}}\left(\right.$ ?) ; wing expanse, $4.28^{\mathrm{nm}}$; greatest width of fore wing, $0.43^{\mathrm{mm}}$. The specimen from which this description is drawn has lost its abdomen, but the other characters are sufficiently marked to found a species. It differs from the preceding species in the following points: The front is coarsely and sparsely punctured, but the punctures are more evenly distributed than in E. vurius, extending down npon the face. The scutellar spot is broad and includes the tip of the mesoscutellum as well as the metascutellum. The leg coloration is as follows: Front coxat nearly pure white, slightly tinged with brownish just at base ; femora yellowish-white, with a longitndinal streak of brown on the dorsal outer side; tibir tinged with brown, tarsi dusks; proximal half of dorsal surface of middle and hind coxa shiny black, rest white; femora rellowish-white, with a longitudinal blackish streak; tibiæ whitish, with fine brown longitudinal lines: tarsi nearly black.

Described from 1 o ( $q$ unkuown) found in jar with eggs of Limenitis dissippus Godt., at Kirkwood, Mo., 1871 (?). [C. V. R. Coll.]

\section{4. (4) Elasmus pullatus, n. sp.}

Male.-Length, 1.39mm ; wing expanse, $3.49^{\mathrm{mm}}$; greatest width of fore wing, $0.46^{\mathrm{mm}}$. Entire surface of body shining black in color, except the antennal pits and the immediate region of the mouth parts, which are honey-yellow; all coxse and femora black, except that the femora are tipped with yellow-brown; anterior tibiae yellowish; tarsi dusky; middle and hied tibice yellow-brown at tip; tarsi dark.

Described from $1 \hat{\delta}$ ( $q$ unknown); bred from Tineid leaf miner on apple (Tischeria malifoliella?) at Kirkwood, Mo., April 1, 1871. [C. V. R. Coll.]

\section{5. (5) Elasmus tischeriæ, n. sp.}

Female.-Dimensions the same as with E. varius. Differs from this species in the following respects: Head less densely punctate and mesonotum more markedly scaly in appearance. Scape of antennie light yellow. Metanotum and base of first joint of abdomen metallic-green. Abciomen with a continnous longitudinal dorsal black stripe, which widens on the last segment and includes the ovipositor; remainder of 
the abdomen honey yellow. Front coxa dirty white, tibixe and tarsi the same; middle and hind coxso nearly black, honey-yellow at either end. Wing veins sligbtly dnsky, not dark brown.

Described from 10 옹 specimens ( $\hat{o}$ unknown) bred from larva of Tischeria solidaginifoliella mining leaves of Solidago in District of Columbia and Northern Virginia. The adult parasites issuerl August 16, 17, and 19, 1884. [Dept. Agr. and C. V. R. Coll.]

\section{LIST OF HOSTS AND PARASITES.}

\section{LEPIDOPTERA.}

Aletia xylina

S Chalcis orate.

Euplectrus comstockii.

Antherai polyphemus. Spilochalcis marice.

Apatura clyton Chalcis orata.

Arctiid larva (unknown) Euplectrus lcucotrophis.

Attacus cynthia. Spilochalots maria.

Botis aluialis. Chalcis ovata.

Bucculatrix pomifoliella.

\{ Encyrtus bucculatricis.

Bucculatrix n. sp. on Oak Cirrospilus flavicinctus.

Cacrecia rosaceana. . Encyrtus bucculatricis.

Callosamia promethia

S Chalcis orata.

\{ Elachistus cacœcia.

Catocala $\mathrm{sp}$...................................... Euplectrus catocala.

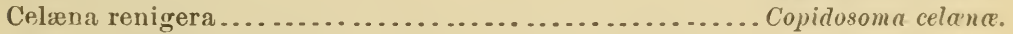

Desmia maculalis...........................................

Gelechia gallæ-asterella ........................... Copidosoma intermedium.

gallæ-solidaginis .................. $\begin{aligned} & \text { Copidosoma gelechin. } \\ & \text { Chalcis ovata. }\end{aligned}$

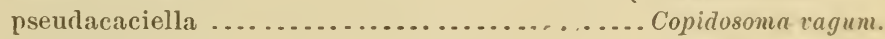

Gracillaria rhoifoliella .............................. Elusmus varius.

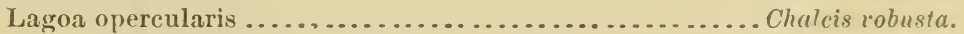

Lithocolletis gregariella .......................... Elasmus nigripes.

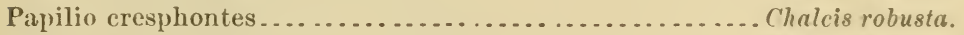

Platyhypena scabra............................. Euplectrus platyhypence.

Proteoteras asculana ............................ Elachistus protenteratis.

Samia cecropia......................................... Spilochalcis maria.

Thyridopteryx ephemeræformis................ \{ Chalcis orata.

Tischeria malifoliella ........................... Elasmus mullatus. solidaginifoliella ........................ Elusuns tischeria.

\section{HEMIPTERA.}

Aspidiotus subcorticis Encyrtus eusifer.

Ceroplastes artemesia. Aphycus ceroplastis.

Dactylopius destructor

S Chiloncurus dactylopii.

Diaspis roses

\{ Leptomuslix dactylopii.

Lecanium hesperidum Iphyeus brunueus.

.

Lecanium sp. on Scotch pine....................... Chilonewrus dubins.

Lecanium sp. on Querens aquatica

SChiloneurus albicornis. Iphycus maculipes. Comys fuser. 
Lecanium sp. on Pinus australis................. $\left\{\begin{array}{l}\text { Encyrtus sublestus. } \\ \text { Coccophagus flavifrons. } \\ \text { Coccophagus koebelei. }\end{array}\right.$

Lecanium sp. on Melia azederach ................... Coccophagus cognatus.

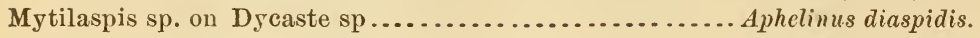

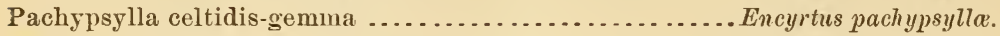

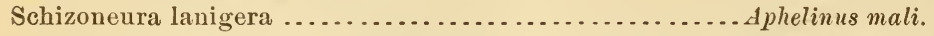

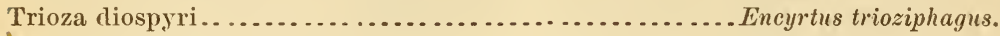

Trioza magnoliæ ................................ Encyrtus solus.

\section{COLEOPTERA.}

Cycloneda sauguinea Homalotylus obscurus.

Odontota sentellaris. Spilochalcis odontota.

HYMENOPTERA.

Pezomachus mininus Spilochalcis albifrons.

\section{DIPTERA.}

Cecidoinyia salicis-siliqua........................ Encyrtus cecidomyix.

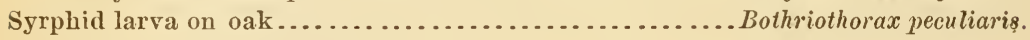
Tachina sp........................................... tachino. 


\title{
LIST OF THE DESCRIBED NORTH AMERICAN SPECIES OF THE FAMILY CHALCIDIDE.
}

\section{Family CHALCIDID $\mathrm{A}$.}

\author{
Subfamily LEUCOSPINÆ.
}

Genus Leucospis Fabr.

AfFinis Say; Leconte's Edition of Say's Writings, i, p. 220. Pennsylvania.

APICALIS Cresson; Transactions of the American Entomological Society, iv (1872-'73), p. 30. Mexico.

azteca Cresson; ibid., p. 33. Mexico.

BASAlis Klug; MSS., Westw., Germar's Zeitschrift fïr Entomologie, i, p. 264, North America.

BULbIVentris Cresson; Transactions of the American Entomological Society, iv (1872-'73), p. 29. Mexico.

dubiosa Cresson; ibid., p. 34. Mexico.

Fraterna Say; Leconte's Edition of Say's Writings, ii, p. 718. Indiana.

integra Haldeman; Proceedings Academy of Natural Sciences, Philadelphia, 2, p. 53. Pennsylvania.

KLUGII Testucood; Germar's Zeitschrift für Entomologie, i, p. 249; tab. 3, fig. 1. Mexico.

MeXicaxa Walker; Journal of Entomology, i, p. 20. Mexico.

PoEy Guérin; Iconographie du Règne Animal, iii, p. 414. Cuba.

smcckard Westwood; Lntomological Magazine, ii, p. 213. North America.

subvotata Пestuood; ibid., p. 215. Nova Scotia.

sumichrastir Cresson; Transactions of the American Entomological Society, iv (187.2-73), p. 31. Mexico.

TEXaNa Cresson; ibid., p. 31. 'Texas.

tolteca Cresson; ibid., p. 34. Mexico.

\section{Subfamily CHALCIDIN Æ.}

Genus Sirrera Spinola.

A BDominalis Walker; Journal of Entomology, i, p. 17\%. Mexico.

ALbifrows ( Walsh); Insects Injurious to Vegetation in Illinois, p. 3\%, fig. 8. Illinois. Ambigua Cresson; Transactions of the American Entomological Society, iv, p. 44. Mexico.

Amowna (Say); Leconte's Edition of Say's Writings, ii, p. 719. Indiana.

AMPX Walker; Annals and Magazine of Natural History, 2d ser., 5, p. 129. West Indies.

ARCANa Cresson; Transactions American Entomological Society, iv, p. 44. Delawaro. azteca Cresson ; ibid., p. 51. Mexico.

BARBARA Cresson; ibid., p. 47. Texas.

broculata Cresson; ibid., p. 43. Texas.

BRACata Cresson; ibid., p. 46. Massachusetts.

Canadexsis Cresson; ibid., p. 39. Canada.

$925 \tilde{5}-5$ ENT- -3 
CAPTIVA Smith; Transactions of the Entomological Society of London, 3d ser., i, p. 42. Panama.

Cardinalis Cameron; Biologia Centrali-Americana, Part xxviii, February, 1884, p. 84 (Tab. v, Fig. 5). Bugaba, Panama.

Centralis Cameron; ibid., p. 89 ('Tab. v, Fig. 6). Presidio, Mexico.

Championi Cameron; ibid., Part xxvii, December, 1883, p. 80 (Tab. v, Fig. 1). Bugaba, Panama.

Coccinata Cresson; Transactions American Entomological Society, iv, p. 48. Mexico. Coccinea Cresson; Proceedings Entomological Society of Philadelphia, iv (1865), p. 91. Cuba.

Compactilis Cresson; Transactions American Entomological Society, iv, p. 50. Mexico.

Conjungens Walker; Notes on Chalcidiæ, Part iii (1871), p. 53. Mexico.

coxalis Cresson ; Transactions American Entomological Society, iv, p.45. Delaware. DEBILIS Say; Leconte's Edition of Say's Writings, ii, p. 720. Indiana.

DECEM-PUnCtata Ashmead; Transactions American Entomological Society, ix (1882), p. xxix. Florida.

Delicata Cresson; Transactions American Entomological Society, iv, p. 54. Texas. Delira Cresson; ibid., p. 41 . Texas.

Delumbis Cresson; ibid., p. 40. Massachusetts; Delaware.

Dimidata Sichel; Annales de la Société Entomologique de France, 4th ser., v, p. 390. Mexico.

DIvisa Talker; Journal of Entomology, i, p. 178. Mexico.

Dorsata Cresson; Transactions of the American Entomological Society, iv, p. 49. Texas.

Dorsimaculata Cameron ; Biologia Centrali-Americana, Part xxviii, February, 1884, p. 95. Guatemala.

DoRsivittata Cameron; ibid., p. 90 (Tab. v, Fig. 2). Panama.

encausta Cresson; ibid., p. 46 . Colorado.

ERXThrina Walker; Jonrnal of Entomology, i, p. 179. Mexico.

eubule Poey, MSS., Cresson ; Proceedings Entomological Society, Philadelphia, iv (1865), p. 93. Cuba.

exorvata Cresson; Transactions American Entomological Society, iv, p. 50. Mexico. Ferrugrea Cameron; Biologia Centrali-Americana, Part xxviii, February, 1884, p. 84. Guatemala.

Fidius Tralker ; Aunals and Magazine of Natural History, 2d ser., 5, p. 129. West Indies.

Flammeola Cresson; Transactions American Entomological Society, iv, p. 48. Mexico. Flavopicta Cresson; Proceedings Entomological Society, Philadelphia, iv (1865), p 99. Cuba.

FLebilis Cresson; Transactions American Entomological Society, iv, p. 39. Massachusetts.

Fulvescens Walker; Entomological Magazine, ii, p. 25. North America.

fulvo-Maculata Cameron; Biologia Centrali-Americana, Part xxviii, February, 1884, p. 93. Bugaba, Pauama.

fulvo-variegata Cameron; ibid., p. 92. Presidio, Mexico.

Geniculata Cameron ; ibid., p. 87 (Tab. v, Fig. 4). Presidio, Mexico.

GIGANTEA Ashmead; Canadian Entomologist, xiii (1881), p. 90. Florida.

GUNDLACHII Cresson; Proceedings Entomological Society, Philadelphia, iv (1865), p. 93. Cuba.

IGNeA Cresson; ibid., p. 92. Cuba.

immaculata Cresson; ibid., p.97. Cuba.

intermedia Cresson; ibid., p,92. Cuba.

Juxta Cresson; Transactions American Entomological Society, iv, p.54. Mexico.

LAMYRUs Walker; The Entomologist (1841), p. 337. Mexico. 
LAUTA Cresson; Transactions American Entomological Society, iv, p. 45. Mexico. LeCta Cresson; ibid., p.44. Mexico.

Lenta Cresson; ibid., p. 52. Mexico.

MaCUlata (Fabricius); Systema Entomologise, ii, p. 198. New York (Walker).

maculicollis Cameron; Biologia Centrali-Anericana, Pt. xxviii, Febr., 1884, p. 88

(Tab. v, fig. $\tilde{\tau}$ ). C'hiriqui, Panama.

MaCulipennis Eameron ; ibid., p. 92. Chiriqui, Panama.

MARIE (Riley); American Entomologist, ii, p. 101 (Febr., 1870). United States, east of the Mississippi.

MENdicA Cresson; Transactions American Entomological Society, iv, p. 41. Mexico. MEXICANa Cresson; ibid., p. 42 . Mexico.

miniata Cameron; Biologia Ceutrali-Americana, Pt. xxviii, Febr., 1884, p. 85. Nicaragua; Guatemala.

Mirabilis Cresson; ibid., p. 53. Georgia ; Texas.

Miranda Cresson; ibid., p. 49. Mexico.

Missouriensis (Howard); ante, p. 6. Saint. Louis, Mo. (Spilochalcis.)

montezuma Cresson; Trausactions American Entomological Society, iv, p. 51. Mexico. Nigricornis (Fabricius); Systema Entomologice, suppl., p. 243. North America.

Nigrifex Walker; Entomological Magazine, ii, p. 22. Georgia.

Nigrifroxs Cameron; Biologia Centrali-Americana, Pt. xxviii, Febr., 1884, p. 91

('Tab. ₹, fig. 9). Bugaba, Panama.

nigriventris Cameron; ibid., p. 96 (Tab. xiv, fig. 14, 14a). Chiriqui, Panama.

nigronaculata Cameron; ibid., p. 83 (Tab. iv, fig. 15, $a, b$ ). San Gerónimo.

NIGropicta Cresson; Proceedings Entomological Society, Philadelphia, iv (1865), p. 94. Cuba.

NoRtoni Cresson; Transactions American Entomological Society, iv, p. 45. District of Columbia.

obtusiventris Cameron; Biologia Centrali-Americana, Pt. xxriii, F'ebr., 1884, p. 93. Presidio, Mexico.

octodentata Cameron; ibid., p. 82. Presidio, Mexico.

octomaculata Cameron; ibid.. p. 88 (Tab. v, fig. 8). Bugaba, Panama.

odontot. (Howard); ante. 1. 7. District of Columbia. (Spilochalcis.)

Panamexsis Cameron; Biologia Centrali-Americana, Pt. xxviii, Febr., 1884, p. 90 (Tab. r, fig. 3). Bugaba, Panama.

PAltexs Cresson ; Proceedings Entomological Society, Philadelphia, iv (1865), p. 96. Cuba.

Petiolata Cresson; ibid., p. 97. Cuba.

Petioliventris Cameron; Biologia Centrali-Americana, Pt. xxviii, Febr., 1884, p. 95. Guatemala.

Pompilioines Thaller; Notes on Clialcidie, Part III, 1871, p. 53. Mexico.

Prativas Walker; Amnals and Magazine of Natural History, 2d ser., 5, p. 130. West Indies.

Pulcura Cresson; Proceedings Entomological Society, Philadelphia, iv (1865), p. 94. Cuba.

puxctata (Fabricins); Systema Entomologia, ii, p. 196. West Indies; Mexico.

PYlas Walker; The Eutomologist (1841), p. 337. Mexico.

Quadridextata Cameron; Biologia Centrali-Americana, Pt. xxvii, 1)ec., 1883, p. 79. Guatemala.

rufofemorata Cresson; Trausactions American Entomolugical society, iv, p. 39.

Texas.

sanguniventris Cresson; ibid., p. 43. Texas.

scutellaris Sichel; Annales de la Sociétó Entomologịne de France, 5th ser., iv. p. 59. Mexico.

Sexdnxtata Camerou; Biologia Centrali-Anericana, Pt. xxviii, Febr., 1-84, p. \&1. Presidio, Mexico. 
side Walker; Annales de la Société Entomologique de France, 2d ser., i, p. 145. Florida.

subobsoleta Cresson; Transactions American Entomological Society, iv, p. 42. Texas. subPunctata Walker; Entomological Magazine, ii, p. 25. Saint Vincent.

TENebrosa Walker; Journal of Entomology, i, p. 181. Mexico.

Tolteca Cresson; Transactions American Entomological Society, iv, p. 53. Mexico. ToluCA Cresson; ibid., p. 42. Mexico.

Torvina Cresson; ibid., p. 40. Massachusetts, Connecticut, Illinois, Texas, Missouri, Virginia.

Transitiva Walker; Transactions Entomological Society, London, 3d ser., i, p. 371. East Florida.

trituberculata Cameron; Biologia Centrali-Americana, Pt. xxviii, Febr., 1884, p. 85. Panama; Guatemala.

VIRENS (Howard); ante, p. 6. Iowa. (Spilochalcis.)

\section{Genus Chalcis Fabr.}

AMoena Say; Leconte's Edition of Say's Writings, ii, p. 719. Indiana.

ANxulipes Walker; Entomological Magazine, ii, p. 29. Saint Vincent.

COLOradensis Cresson; Transactions American Entomological Society, iv, p. 60.

Colorado.

Columbiana Hou'ard; ante, p. 8. District of Columbia.

Cомiтator Walker; Transactions Entomological Society of London, 3d sor., i, p. 350. Mexico.

Compacta Walker; Journal of Entomolugy, i, p. 183. Mexico.

DEBELIS Say; Leconte's Edition of Say's Writings, ii, p. 720. Indiana.

InCERTA Cresson; Proceedings Entomological Society, Philadelphia, iv (1865) p. 101. Cuba.

LASNieri Guérin ; Iconographie du Régnè Animal, iii, p. 412; tab. 67, fig. 4. Cuba. Microgaster Say; Leconte's Edition of Say's Writings, i, p. 219. Pennsylvania. minuta Fabricius; Systema Entomologiæ, ii, p. 195. Georgia.

PEDAlis Cresson; Transactions American Entomological Society, iv, p. 60. Texas. PENDATOR Walker; Transactions Entomological Society of London, 3d ser., i, p. 351.

San Domingo.

oсто-готатA Harris; Catalogue of the Insects of Massachusetts, 2d ed. Massachusetts.

ovatA Say; Leconte's Edition of Say's Writings, i, p. 219. Eastern United States. PUbescers Walker; Notes on Chalcidix, iii, p. 47. Mexico.

REstituA ITalker; Transactions Entomological Society of London, 3d ser., i, p. 351. Jamaica.

Robusta Cresson; Proceedings Entomological Society, Philadelphia, iv (1865), p. 101. Cuba; Florida.

TACHIN Howard; ante, p. 8. New Hampshire.

TEGUlaRIS Cresson; Transactions American Entomological Society, iv, p. 60. Texas.

Genus Haltichella Spinola.

AMERICANA Howard; ante. p. 9. Virginia.

Crassicauda (Sichel); Annales de la Société Entomologique de France, Ser. 4, iv, p. 377 (Tab. 10, fig. 1). (Phasgonophora.)

INsUlaris (Cresson); Proceedings Entomological Society of Philadelphia, iv (1865), p. 102. Cuba. (Described as Phasgonophora.)

onatas ( Nalker); Annales de la Société Entomologique de France, 2d ser., i, p. 146. Florida. (Deseribed as Hockeria.)

onNaticollis Cameron; Biologia Centrali-Americana, Pt. xxxi, July, 1884, p. 100. Bugalua, Panama. 
PERPULChrA (Walsh); Insects Injurious to Vegetation in Illinois, p. 42. Illinois. (Described as Hockeria.)

RUfitarsis (Cameron); Biologia Centrali-Americana, I't. xxxi, July, 1884, p. 93 (Tab. v, figs. 10, $a, b, c, d)$. Chiriqui, Panama. (Phasgonophora.)

runivextris (Sichel); Anuales de la Société Entomologique de France, ser. 4, v, p. 360 ('Tab. 9, fig. 4). (Phasgonophora.)

sulcata (Westwood); Griffith's Animal Kingdom, xv, p. 432. Georgia. (Describel as Phasgonophora.)

xaxticles (Walker); Anuales de la Société Entomologique de France, 2d ser., i, p. 14\%. Floridla. (Described as Hockeria.)

Genus ACaxthochalcis Cameron.

NigriCaxs Cameron; Biologia Centrali-Americana, Pt. $x x x i, J u l y, 1884$, p. 101 (Tal. vi, figs. 14,14a). Sonora, Mexico.

\section{Genus Epitraxus Walker.}

Castanets Cresson; Proceedings Entomological Societs, Philadelphia, iv (1=65), p. 100. Cuba.

Fulvescexs Walker ; Entomological Magazine, ii, p. 26. Saint Vincent.

Genus Notaspis Walker.

Formiciformis Walker; Entomological Magazine, ii, p. 38. Saint Vincent.

Subfamily EUCHARINÆ.

Genus Lirata Cameron.

Luteogaster Cameron; Biologia Centrali-Americana, Pt. xxxi, Juls, 1884, p. 102 (Tab. r, figs. 16, 16a). Taboga, Panama.

Genus Lophyrocera Cameron.

Nigromaculata Cameron; ibid., p. 104 (Tab. \&, figs. 19, $a, b$ ). Nicaragua. stramineipes Cameron; ibid., p. 103 (Tab. v, figs. 18, a). Panama.

\section{Genus Orasema Cameron.}

stramineipes Cameron; ibid., p. 105 (Tab. v, figs. 20, $a, b, c ;$ vi, 18, $a, b, c, d, e$ ). Panama.

\section{Subfamily PERILAMPIN玉.}

Genus Perilanes Latreille.

ALExixcs Tralker; List of the Specinens of Hymenopterous Insects in the Collection of the British Museum. Part I, Chalcidites (1846), appeudix, p. E9. Georial. Craxecs Brullé; Histoire Naturelle des Insectes, Hyuménoptères, 1546, p. 573. Carolina.

Extelles Walker; Anuals of Natural History, xii, p. 103. Ohio. HYalines Say; Leconte's Edition of Say's Writings, i, p. 38.2. Pennsylvania. LePreos Walker; British Museum Catalogues, Chalcidites, i, appendix, p. 89. Georgia. Platigaster Say; Leconte's Edition of Say's Writings, ii, p. F.:. Indiana.

TRIANGULARIS Say; ibid., i, p. 381 . Indiana. 


\section{Subfamily EURYTOMIN E.}

\section{Genus Eurytoma Rossi.}

abatos Walker; Annales de la Société Entomologique de France, ser. 2, i, p. 152. Florida.

ABNORNhCORNIS Walsh ; American Entomologist,ii,p. 299. Illinois.

ALBIPES Ashmead; Transactions American Entomological Society, ix (1882), p. xxxi. Florida.

argentata Cameron; Biologia Centrali-Americana, Part xxxi, July, 1884, p. 108. Guatemala.

AURICEPS Walsh; American Entomologist, ii, p. 289. Illinois.

AUrifrons Cameron; Biologia Centrali-Americana, Part xxxi, July, 1884, p. 108

(Table V, Figs. 11, $a, b, c, d, e)$. Guatemala.

BICOLOR Walsh; ibid., p. 298. Illinois.

Bolteri Riley; First Missouri Entomological Report, p. 177. Missouri.

Cretheis Walker; Annales de la Société Entomologique de France, 2d ser., i, p. 150.

Florida.

DIAstrophi Walsh; American Entomologist, ii, p. 299. Illinois.

FUNebris Howard; Amuual Report U. S. Commissioner of Agriculture, 1879, p. 196.

District of Columbia.

GIGANTEA Walsh; American Entomologist, ii, p. 300. Illinois.

HECALE Walker; Annales de la Société Entomologique de France, 2d ser., i, p. 151. Florida.

IPHIS Walker; British Museum Catalogues, Chalcidites, i, appendix, p. 85. Florida. LANUle Fitch; Fifth Report on the Noxious Insects of New York, p. 3\%. New York. orbiculata Say; Leconte's Edition of Say's Writings, ii, p. 720. Indiana.

Petrolivextris Cameron; Biologia Centrali-Americana, Part xxxi, July, 1884, p. 108 (Table V, Fig. 12). Panama.

PHylloXere Ashmead; Transactions American Entomological Society, ix (1882), p.

xxx. Florida.

Prunicola Walsh; American Entomologist, ii, p. 298. Illinois. Var. globulicola, ibid. PUNCTIVENTRIs Walsh; ibid., p.299. Illinois.

Phythes Walker; Annales de la Socí́té Entomologique de France, 2d ser., i, p. 154. Florida.

studrosa Say; Leconte's Edition of Say's Writings, ii, p. 721. Indiana.

succinipedis dshmead; Transactions American Entomological Society, ix (1882), p. xxxi. Florida.

teredon Walker; Annales de la Société Entomologique de France, 2d ser., i, p. 153. Florida.

VAGABUNDA Ashmead; Canadian Entomologist, xiii (1881), p. 134 . Florida.

\section{Genus Decatoma Spinola.}

Antiqua Scudder ; Bulletin U. S. Geological Survey, iv, p. 749. Fossil in Green River shales, Colorado.

Batatoldes Ashmead; Canadian Entomologist, xiii, p. 136́. Florida.

BICOLOR Ashmead; Transactions American Entomological Society, ix (1882), p. xxxii. Florida.

Catesbei Ashmead; ibid. Florida.

FLAVA Ashmead; Canadian Entomologist, xiii, p. 135. Florida.

FOLIATE Ashmead; ibid., p. 136. Florida.

Hyalipennis Walsh; American Entomologist, ii, p. 301. Illinois.

LAx.e Ashmead; Canadian Entomologist, xiii, p. 135. Florida.

NIGRICEPS Walsh: American Entomologist, ii, p. 300. Illinois. Var. excrucians, ibid. nubilistigma Walsh; American Entomologist, ii, p. 301. Illinois. 
oretilla Walker; Annals of Natural Histors, xii, p. 46. Saint Vincent.

PHellos Ashmead; Canadian Entomologist, xiii, p. 136 . Florida.

QUERCI Ashmead; Canadian Entomologist, xiii, p. 135. Florida.

siniplicistigna Walsh; American Entomologist, ii, p. 301. Illinois.

VARIANS Walsh; ibid., p. 300 . Illinois.

Genus Isosovi Walker.

ELYMI French; Canadian Entomologist, xiv (1£ะ2), p. 10. Illinois.

GRANDE Riley; Bulletin of the Brooklyu Entomological Society, vii, p. 111 (December, 1884). Indiana; Ohio.

morder (Harris); New England Farmer, ix, No. 1, p. 2 (July 23, 1830). Eastern United States. (Described as Eurytoma.)

Tríric Riley; Americau Naturalist, xvi, p. 21s (March, 1982). Kentucky; Missouri; Illinois; Indiana; Washington Territory.

vitis Saunders; Canadian Entomologist, ii, p. 26 (November, 1869). Canada.

Gemus Bephrata Cameron.

RUficollis Cameron; Biologia Centrali-Americana, Part xxxi, July, 18ษ4, p. 109 (Table V, Figs. 13, a). Panama.

Subfamily AXIMINE.

Genus Hoxtalia Cameron.

CARUled Cameron; ibid., p. 113 (Table VI, Figs. 1, a). Nicaragua.

ruficornis Cameron; ibid., p. 113 (Table VI, Figs.2, a, b, c). Рauama.

Subfamily TORYMIS.E.

Genus Dromorus Walker.

MaYri Cameron; ibid., p. 106 (Table iv, Figs. 17, $a, b$ ). Guatemala. RUFIPES, Cameron; ibid., p.105. Guatemala.

Genus Syxtomaspis Förster.

MaCulipexyis Cameron; ibid., p. 10\%. Sonora, Mexico.

Genus Megastigius Dalman.

PIyus Parfitt; The Zuologist, 15, p. 5543. Califoruia.

Geuus Callimome Spiuola.

Auvexa Osten-Sacken; Transactions American Entomological Society, iii, (18r0-'71), p. 59. District of Columbia.

EA Walker; Annals of Natural History, xii, p. 104. Now York.

ExEA Ashmead; Trausactions American Entomological Society, ix (1:52), p. xxxiii. Florida.

BREviCaUda Osten-Sacken ; ibid., iii, p. 62. District of Columbia. (

BrevissmicaUda dshmead; ibid, ix, p. xxiii. Florida.

C.ERULEA Ashmead; ibid. Florida.

CECIDomyix Walker; Annals of Natural History, 14, p. 15. Hndson's Bay.

Curysochlora Osten-Sacken: Transactions American Entomological Society, iii, p.

63. New England.

DURA Osten-Sacken; ibil., p. 59. Nul.loc.

elegantissina Ashmead; ibid., ix, p. xxiv. Florida. 
Flavicoxa Osten-Sacken; ibid., iii, p. 61. Nul. loc.

LISsus Walker; Annales de la Société Entomologique de France, 2d ser., i, p. '150. Florida.

MagNifica Osten-Sacken; Transactions American Entomological Society, iii, p. 62. Nul. loc.

reCEMARIE Ashmead; ibid., ix, p. xxxiii. Florida.

Solitaria Osten-Sacken; ibid., iii, p, 64. Nul. loc.

sPLENDIDUS Barnstone MSS., Walker ; Annals of Natural History, 14, p. 14. Hudson's Bay.

THEon Walker; Annales de la Société Entomologique de France, 2d ser., i, p. 149. Florida.

TUBICOLA Osten-Sacken; Transactions American Entomological Society, iii, p. 60. District of Columbia.

virentis Ashmead; ibid., ix, p. xxxiv. Florida.

\section{Genus Torymus Dalman.}

АMeтhystives Harris; Catalogue of the Insects of Massachusetts, $2 d$ ed. Massachusetts.

AZALE E Harris; ibid. Massachusetts.

ochreatus Say; Leconte's Edition of Say's Writings, ii, p. 723. Indiana.

Pavidus Say; ibid. Indiana.

SRMIaURATUs Harris; Catalogue of the Insects of Massachusetts, $2 \mathrm{~d}$ ed.

Genus Ormyrus. Westwood.

LABotus Talker; Annales de la Socí́t6 Entomologique de France, ser. 2, i, p. 148. Florida.

Genus IDaRnes Walker.*

CARME Walker; Annals of Natural History, 12, p. 47. Saint Vincent.

Subfamily EUPELMINæ.

Genus Eupelirus Dalman.

Albispina Cameron; Biologia Centrali-Americana, Pt. xxxi, July, 1884, p. 120. Panama.

ALLYNII (French); Canadian Entomologist, xiv (1882), p. 9. Illinois. (Described as Isosoma.)

Bimaculatus Cameron; Biologia Centrali-Americana, Pt. xxxi, July, 1884, p. 120. Panama.

BRevicornis Cameron; ibid., p. 117. Panama.

BUCCUlatricis Howard MSS.; Brunn, in Second Report Department Entomology, Cornell University Experiment Station (1883), p. 161. New York.

Cingulatus Cameron; Biologia Centrali-Americana, Pt. xxxii, Aug., 1884, p. 122. Guatemala ; Panama.

Compressicornis Cameron; ibid., Pt. xxxi, July, 1834, p. 115 (Tab. vi, fig. 12). Panama.

CYNIPIDIS Ashmead; Canadian Entomologist xiv, p. 37. Florida.

EPICASTE Walker; Annals of Natural History, 20, p. 20. North America.

erythrothorax Cameron; Biologia Centrali-Americana, Pt. xxxii, Aug., 1884, p. 121. Panama.

Fascilventris Cameron; ibid., p. 123. Panama.

* I am not familiar with this genus. and place it only on the authority of a suggestion. in Walker's notes on the Aogonidre. L. O. H. 
Flavipes Cameron; ibid., p. 122. Guatemala.

FLORIDANUS Howard; Canadian Entomologist xii (1880), p. 209. Florida.

Foxtera Walker; Annals of Natural History, 20, p. 19. North America.

Gexiculatus Cameron; Biologia Centrali-Americana, Pt. xxxi, July, 1881, p. 119. Panama.

GIGAS Cameron; ibid., p. 116 (Tab. vi, figs. 9,a). Panama.

GRaCIlis Cameron; ibid., Pt. xxxii, Aug., 1884, p.121. Guatemala.

HYALINIPENxis Cameron; ibid., p. 121. Guatemala.

LaMaches Walker; ibid., p. 20. North America.

Mirabilis (Walsh); American Entomologist ii, p. 369. Illinois. (Described as $A n$ tigaster, nov. gen.)

Petiolaris Cameron; Biologia Centrali-Americana, Pt. xxxii, Aug., 1884, p. 123. Guatemala.

REDUVII Howard; Canadian Entomologist xii, p. 207. District of Columbia.

ROS. Ashmead; ibid., xiv, p. 36 . Florida.

testaceus Cameron; Biologia Centrali-Americana, Pt. xxx, July, 1884, p. 117 (Tab. vi, figs. 10,a). Panama.

testaceicoras Cameron; ibid., p. 119. Panama.

\section{Genus Brasema Cameron.}

BRevispina Cameron; ibid., Pt. xxxii, Aug., 1884, p. 124. Guatemala.

\section{Genus Aseirba Cameron.}

CaUdata Cameron; ibid., p. 128 (Tab. vi, fig. 13). Nul. loc.

\section{Genus Lutues Cameron.}

CRASSICORxis Cameron; ibid., p. 126 (Tab. vi, fig. 15). Panama.

DROMEDARIUS Cameron; ibid., p. 126. Panama.

LONGIVExtris Cameron; ibid., p. 127. Panama.

orNaticollis Cameron; ibid., p. 125 (Tab. vi, Figs. 16, a). Panama.

Genus Metapelya Westwood.

SPECTarilis Westuood; Proceedings of the Zoological Society, 1835, p. 69. Georgia.

\section{Subfamily ENCYRTIN王.}

\section{Geuus Rhopus Förster.}

Coccors (E. A. Smith)'; North American Entomologist, i., p. (Described as Acerophagus, nor. gen.)

\section{Genus Aphycus Mayr.}

Axxulipes (Ashmead); Canadian Entomologist, xiv, p. 3\%. Florida. (Described as a Coccophagus.)

BRUNxeys Howard; ante, p. 17. New Jersey.

Ceroplastis Houard; ante, p. 13. New Mexico.

ERUPTOR Howard; Annual Report U. S. Commissioner of Agriculture, 18s0, p. 36 .

Florida; Virginia.

Flaves Houard; ibid., p. 365. Florida.

MACUlipes Hotcard; ante, p. 1\%.. South Carolina.

PULYNARIE Howard; Annual Report U.S. Commissioner of Agriculture, 1880, p. 36.5.

Iowa. 


\section{Genus Blastothrix Mayr.}

AdJUTABILIS Howard; ibid., p. 365 . Florida; Virginia. INCERTA Howard ; ibid., p. 366 . Florida. LONGIPENNIS Howard; ibid., p. 366 . District of Columbia.

Genus Encyrtus Dalman.

ARTACEA Howard; ibid., p. 252. Florida.

Bolus Walker; Annals of Natural History, 14, p. 17. Hudson's Bay.

BUCCUlatricis Howard; Lintuer's First Report as State Entomologist of New York

(1882), p. 160. New York; Missouri ; District of Columbia.

CECIDOMYid Howard; ante, p. 16. Virginia.

ENSIFER Howard; ante, p. 13. Florida.

FlacCUS Walker; Annals of Natural History, 20, p. 21. North America.

Flavus Howard; Annual Report U. S. Commissioner of Agriculture, 1880, p. 367. California.

FUSCICORNIS Howard; ante, p. 13. Maryland.

GARGARIS Walker; Annals of Natural Histor 5,12 , p. 47. Saint Vincent.

GaSTRON Walker ; ibid., 20, p. 21 . North America.

HYETTUS Walker ; ibid., 17, p. 181 . Saint Vincent.

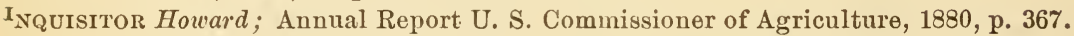
Florida.

Montinus Packard; Geology of New Hampshire, vol. i, Final Rept., chap. xii, p. 347. New Hampshire.

PACHYPSYlle Howard; ante, p. 15. Maryland.

PUNCTICEPS Howard; ante, p. 14. Virginia.

REATE Walker ; Annals of Natural History, 20, p. 22. North America.

solus Howard; ante, p. 15. Florida.

SUBLESTUS Howard; ante, p. 12. Florida.

TRIOZIPHAGUS Howard; ante, p. 14. District of Columbia.

TURni Packard; Proceedings Boston Society of Natural History, xxi, p. 32. Nul. loc., vectius Walker ; Annals of Natural History, 20, p. 21. North America.

\section{Genus Psilophrys Mayr.}

HYALINIPENNis Howard; ante, p. 21. Missouri.

\section{Genus Leptomastix Förster.}

DACTYlOpir Howard; ante, p. 23. District of Columbia.

Genus Copidosoma Ratzeburg.

CELAN Howard; ante, p. 11 . Missouri.

GELECHI Howard; ante, p. 10. District of Columbia; New Hampshire; Missouri. INTERMEDIUM Howard; ante, p. 12. New Jersey.

vaGuM Howard; ante, p. 11. Missouri.

\section{Genus Сомys Förster.}

BICOLor Howard; Annual Report U. S. Commissioner of Agriculture, 1880, p. 362. District of Columbia.

FUSCA Howard; ibid., p. 363. Alabama.

Genus Chiloneurus Westwood.

ALBICORNIS Howard; ibid., p. 363. District of Columbia; Iowa; South Carolina. DUBIUS Howard; ante, p.17. Wisconsin.

DACTYLOPII Howard; ante, p. 17. District of Columbia. 
Genus Homalotylus Mayr.

oBscurus Howard; ante, p.22. Florida.

Genus Botmiothorax Ratzeburg.

PECULIARIS Howard; ante, 1.20. Virginia.

VIRGINIENSIs Howard; ante, p.20. Virginia.

\section{Subfanils APHELININA.}

Genus Coccopiragus Westwoorl.

ATEr Howard; Annmal Report U. S. Commissioner of Agriculture, 1880, p. 359. New York.

Cognatus Howard; ibid., p. 359. District of Columbia.

FLAVIERONS Howard; ante, 1). 25. Florida.

Fraterisus Howard; Annual Report U. S. Commissioner of Agricultire, 1880, p. 359.

District of Columbia.

FUSCIPES Howard; ibid., p. 359. Florida.

immaculatus Howard; ibid., p. 358. District of Columbia.

KOEBELEI Howard; ante, p. 25. Florida.

LECANII (Fitch); Fifth Report as State Entomologist of New York, p. 25. New York;

Illinois ; District of Colnmbia ; California. (Described as Platygaster.)

VARICORNis Howard; Anmual Report U. S. Commissioner of Agriculture, 1880, p. 360.

District of Columbia.

vividus Howard; ante, p. 24. Florida.

Genus Aphelints Dalman.

ABNorins Howard; Annual Report U. S. Commissioner of Agriculture, 1880, p. 355. District of Colnumbia.

Aspidioticola Áshmead; Canadian Eutomologist xi (1879), p. 159. Florida. (Evidently a Mymarid.)

niaspidis Howard; Annual Report U. S. Commissioner of Agriculture, 1880, p. 355. Floricla; California.

FUscipenvis Howard; ibid., p. 356. Florida; California; District of Columbia.

mali (Haldeman); Proceedings Boston Society of Natural History, vi, p. 403. Pennsylvania ; Illinois; Missonri ; District of Columbia. (Described under Eriophilus, nov. gen.)

MYTIlaSPIDis Le Baron; American Entomologist, ii, p. 360. Illinois ; Missouri ; New York; California ; District of Columbia.

pulciellus Howard ; Anuual Report U. S. Commissioner of Agriculture, 1880, p. 356. District of Colmmbia.

\section{Subfanily PIRENIN AE.}

Genus Macroglenes Westwood.

QUerci-glonuli Fitch; Fiftl Report as State Entomologist of Now York, p. 32. New York.

QUercI-PISI Fitch; ibid., p. 39. Now York.

\section{Genus Tomocera Howard.}

Calfrorsica Howard; Ammal Report U. S. Commissioner of Agriculture, 1880, p. 363. California. 
Subfamily SPALANGIINA.

Genus Spalavgius Latreille.

Chontalensis Cameron; Biologia Centrali-Americana, Part xxxi, July, 1884, p. 110

(Table v, Figs. 14, a). Nicarangua.

Polrtus Say; Leconte's Edition of Say's Writings, i, p. 382. Virginia.

QUERCI-LAN E Fitch; Fifth Report as State Entomologist of New York, p. 36. New York.

SYRPHI Ashmead; Canadian Entomologist, xiii, p. 171. Florida.

Genus Paralesthesia Cameron.

Mandibularis Cameron; Biologia Centrali-Americana, Part xxxi, July, 1884, p. 111 (Table v, Figs. 15, $a, b, c, d$ ). Panama.

\section{Subfamily PTEROMALINE.}

Genus Lamprotatus Westwood.

cyrnus Walker; Annales de la Société Entomologique de France, 2d ser., i, 157. Florida.

DIseUs Walker; Annals of Natural History, 14, p. 16. Hudson's Bay.

HABIS Walker; Annales de la Société Entomologique de France, 2d ser., i, p. 155. Florida.

salemus Walker; ibid., p. 156. Florida.

TRYPHENUS Walker; ibid., p. 158. Florida.

Genus Micromelus Walker.

CYRENE Walker; ibid., p. 154. Florida.

Genus GLyphe Walker.

VIRIDASCENS Walsh; Insects Injurious to Vegetation in Illinois, p. 38, fig. 9. Illinois.

Genus Epistenia Westwood.

Coerulata Westwood; Griffith's Animal Kingdom, 15, p. 432. Georgia.

Genus Lelaps Halliday.

PULCHRICORNIS Halliday; Transactions Entomological Society of London, vol. iii, p. 300. Saint Vincent.

Genus Pachyneuron Walker.

albutius Walker; Annales de la Société Entomologique de France, 2d ser., i, p. 158. Florida.

altiscuta Howard, MSS., Cook, A. J. ; Notes on Injurious Insects ; Entomological Lab oratory, Michigan Agricultural College, Augıst, 1884, p. 13. Michigan.

Genus Cheiropachys Westwood.

NIGRo-CYANeus Norton; Transactious American Eutomological Society, ii, p. 327. Connecticut.

Genus Semiotellus Westwood.

Chalcidiphagus Walsh; American Entomologist, ii, p. 368 . Canada; Virginía.

CLISIOCAMP Fitch; Second Report as State Entomologist of New York, p. 200. New York. (Described as Cleonymus.)

DestruCtor (Say); Leconte's Edition of Say's Writings, ii, p. 6. Northern United States. (Described as Ceraphron.) 
Genus Stictonotus Förster.

Isosomatis Riley; Annual Report U. S. Commissioner of Agriculture, 1881-'82, p. 186. Tennessee.

\section{Genus ExtruUs Walker.}

SCYMNE Shimer; Transactions American Entomological Society, ii, p. 385. Illinois.

Genus Pterodralus Swederus.

ARCTIE Harris ; Catalogue of the Insects of Massichusetts, 2d ed.

CAlandre Howard; Annual Report U. S. Commissioner of Agriculture, 1880, p. 273.

Texas.

CAssotis Walker ; Annals of Natural History, 19, p. 893. North America.

CLISIOCAMPE Harris; Catalogne of the Insects of Massachusetts, $2 \mathrm{~d}$ ed.

Clatylus Walker; Annals of Natural History, 19, p. 392. North America.

DAxo Walker; ibid., p. 395. North America.

DIPSUs Walker; ibid., p. 394. North America.

DORYssus Walker; ibid., p. 395. North America.

DYMNUS Walker; ihid., p. 397. North America.

EPICLES Walker; ibid., p. 394. North America.

ERYX Walker; ibid., p. 397. North America.

EURYPON Walker; ibid., p. 398. North America.

еUTHYMUS Walker; ibid., p. 393. North Aınerica.

GELECHIE Webster; Twelfth Report of the State Entomologist of Illinois (1882), p. 151.

Illinois.

HeLICE Walker; Annals of Natural History, 12, p. 46. Saint Vincent.

hermeas Walker; ibid., 19, p. 394. North America.

HYBREAS Walker; ibid., p. 397. North America.

LAUsus Walker; ibid., p. 392. North America.

LEPTURUS Harris; Catalogue of the Insects of Massachusetts, $2 \mathrm{~d}$ ed. OBESUS Harris; ibid.

EAX Falker ; Annals of Natural History, 19, p. 395. North America.

onerate Fitch; Fifth Report as State Entomologist of New York, p. 32. New York. orontas Walker; Annals of Natural History, 19, p. 396. North America.

QUADRI-MaCUlate Ashmead; Canadian Entomologist, xiii, p. 171. Florida.

QUERCI-PILLULE Fitch; Fifth Report, p. 39. New York.

TABACCUn Fitch; Ninth Report, p. 79.2. New York.

TIM⿻A Walker; Annals of Natural History, 19, p. 396. North America.

VANNESS Harris; Catalogue of the Insects of Massachnsetts, $2 d$ ed.

verditer Norton; Transactions American Entomological Society, ii, p. 32\%. Nul. loc.

Genus Metoron Walker.

Derphon Walker; Annales de la Société Entomologique de France, 2d ser., i, p. 161. Florida.

Subfamily ELACHISTIN ※.

Genus Euplectrus, Westwood.

BICOLOR (Swederus); Kongl. Vet. Ac. Handl., 1795, 204, 2. Saint Vincent. (Described as Pteromalus.)

CatOcalæ Howard; ante, p. 27. Missouri ; Maryland.

coмsтоски Howard; Canadian Entomologist, xii (1880), p. 159. Alabama.

Frontalis Howard; ante, p.27. Virginia.

rurnius Walker; Annals of Natural History, 12, p. 48. Saint Vincent.

L.eucotrophrs Howard; ante, p. 26. Florida.

PLATYHYPENA: Howard ; ante, p. 26. District of Columbia. 
Genus Stenomesius (?) Westwood.

APHIDICOLA Ashncad; Orange Insects (Jacksonville, 1880), p. 67. Florida.

Genns Elachistus Spinola.

CACCECIXE Howard; ante, p. 28. Missouri.

CoXalis Howard; ante, p. 2\%. District of Columbia.

LeVANA Walker; Annals of Natural History, 20, p. 2i. North Ainerica.

proteoteratis Howard; ante, p. 27. Missouri.

\section{Genus Cirrospilus IVestwood.}

Eunapius 1 alker; Annals of Natural History, 20, p. 27. North America.

FLA Vicinct Us Riley; Lintner's First Report as State Entomologist of New York (1882), p. 159. Missouri.

Subfamily ELASMIN F.

Genus Elasmus Westwood.

ALBICOXA Howard; ante, p. 30. Missouri.

NIGRIPES Howard; ante, p. 30. Missouri.

PUllatus Howard; ante, p. 30. Missouri.

TISCHERIE Howard; ante, p. 30. District of Columbia.

VARIUS Howard; ante, p. 29. Missouri.

Subfamily EULOPHINÆ.

Genus Sympiezus Förster.

Lithocolletidis Howard MSS.; Brunn in Second Report Department of Entomology, Cornell Unirersity Experiment Station (1883), p. 150. New York.

\section{Genus Eulopius Geoffrey.}

BASALIS Say; Leconte's Edition of Say's Writings, ii, p. 721. Indiana. CALAvius Walker; Annals of Natural History, 20, p. 24. North America. CYRIADES Walker; ibid., p. 25. North America.

DICLAdus Say; Leconte's Edition of Say's Writings, ii, p. 721. Indiana. GORBRYAS Walker; Annals of Natural History, 20, p. 26. North America. Hircinus Say; Leconte's Edition of Say's Writings, ii, 722. Indiana. IPINOË Walker; Annals of Natural History, 20, p, 25. North America. mINIs Talker; ibid. North America.

Minutus Howard MSS.; Brunn in Second Report Department of Entomology, Cornell

University Experiment Station (1883), p. 150. New York.

MiNYAS Walker; Annals of Natural History, 20, p. 25. North America.

SEMidiæ Packard; Report Geology New Hampshire, i (1874), p. 347, fig. 46 . New Hampshire.

Sa Undersir Packard; Proceedings Boston Society of Natural History, vol.xxi (1880), p. 34. Canada.

THECL瓜 Packard; ibid. Nul. loc.

Genus Anthophorabia Newport.

Megachilis Packard; Proceedings Essex Institute, iv., p. $13 . \quad$ Nul. loc. 


\section{Subfamily ENTEDONINE.}

Genus extedon Dalman.

ANTIOP王 Packard; Proceenings Boston Society of Natural History, $\mathbf{x} x \mathbf{1}(18 \varepsilon 0)$, p. 36. Nul.loc.

Diastate Howard; Annual Report U.S. Commissioner of Agriculture, 1800, p. 246. District of Columbia.

Herilles Walker ; Aunals of Natural History, 20, p. 23. North America.

IMBRASUS Walker; ibid. North America.

SARDUS Walker; ibid. North America.

Genus Derostexus Westwood.

TISCHFrie (Hovard MSS.); Brunn in Second Report Department of Entomologs, Cornell University Experiment Station (1833), p.157. (There mentioned as an Astichus.)

Subfamily TETRASTICHIXE.

Genus Grrolasia Förster.

Flavimedia Howard; Annual Report L.S. Commissioner of Agriculture, 1880, p. 369. California.

\section{Genus Tetrastichus Halliday.}

EPIDICS Walker; Annals of Natural Histors. 20, p. 28. North America.

ESURUS (Riley); Canadian Entomologist, xi (1879), p. 16\%. Southern United States. (Described as a Cirrospilus.)

GALA Walker; Annals of Natural History, 20, p. 28. North America.

GRANulatus Walker; ibid., 14, p. 17. Hudson's Bay.

LAEMON Walker; ibid., 20, p. $2 \&$. North America.

\section{Subfamilঙ TRICHOGRAMMIN王.}

\section{Genus Trichogramma Westwood.}

I Fratersa Fitch; Second New York Report, p. 217. New York.

FLAVUS Ashmead; Orange Insects (1=₹0), p. 33, pl. i. Florida.

Mnvta Riley; Third Missouri Entomological Report, p. 158. Missouri.

minutissmum Packard; Proceedings Boston Society of Natural History, xxi (18s0), p. 37. Nul. loc.

I oRgYi® Fitch; Second New York Report, p. 216. New York.

PRETJOSA Riley; Canadian Entomologist, xi (1879). p.161. Southern United States. 
